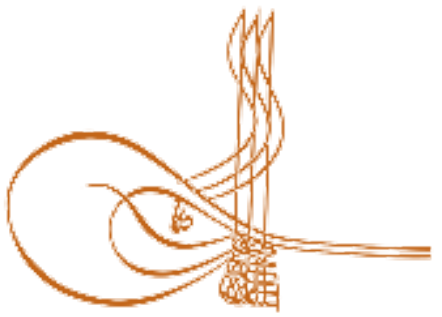

www.turkishstudies.net/education
Turkish Studies - Educational Sciences

eISSN: $2667-5609$

Research Article / Araștırma Makalesi

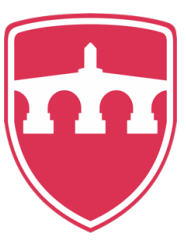

INTERNATIONAL

BALKAN

UNIVERSITY

Sponsored by IBU

\title{
Bir Matematik Öğretmeninin Bilimin Doğası Hakkındaki Görüşleri: Bir Tekli Durum Çalışması"
}

\author{
A Math Teacher's Opinions About The Nature of Science: A Single Case Study
}

\author{
Erol Süzük ${ }^{* *}-$ Gökhan Derin ${ }^{* * *}-$ Emin Aydın ${ }^{* * * *}$
}

\begin{abstract}
In this study, it was aimed to examine a typical mathematics teacher's views about the nature of science in depth. He did not take any courses on the history of science and the nature of science during his university education. In order to determine the participant's views, data were collected by a semi-structured interview form which was developed with using "Views on Nature of Science Questionnaire, Form C) (VNOSC) developed by Abd-El-Khalick et al. (2001). There are 10 open-ended questions in the interview form. Before starting the interview, the participant were informed that s/he could leave the research without any reason at any time. After the written consent of the participant, the interviews were held with the participant 4 times a week in April 2018. The data obtained were analyzed with the qualitative data analysis method. As a result of this analysis, a concept map was obtained which shows the views of the participant about the nature of science. According to the findings, the participant has misconceptions about the nature of science as there is a universal method in science, that there is a direct proportion between the number of experiments and observations and the accuracy of the information, that a theory is an approved hypothesis and that there is a hierarchical structure between the theory and the law. On the other hand, the participant thinks that science is measurable and can be proved, that technology is a tool for science, that theories can change, that scientists can reach different results by using the same data, that science is affected by social and cultural values and that scientists use their imagination and creativity. It can be suggested that teachers working in private schools can also be trained to eliminate misconceptions about the nature of science by providing them to participate in in-service training
\end{abstract}

\footnotetext{
${ }^{*}$ Bu çalışmanın verileri 2018 yılında toplanmış ve çalışma dergiye değerlendirilmek üzere 2019 yılında gönderilmiştir.

${ }^{* *}$ Dr. Öğr. Üyesi, Marmara Üniversitesi, Atatürk Eğitim Fakültesi, Matematik ve Fen Bilimleri Eğitimi Bölümü Asst Prof., Marmara University, Ataturk Faculty of Education, Mathematics and Science Education ORCID 0000-0001-5520-5597 erol.suzuk@marmara.edu.tr

${ }^{* * *}$ Doktora Öğrencisi, Marmara Üniversitesi, Atatürk Eğitim Fakültesi, Matematik ve Fen Bilimleri Eğitimi Bölümü PhD Student, Marmara University, Ataturk Faculty of Education, Mathematics and Science Education ORCID 0000-0003-3547-4997 gokhanderin29@gmail.com

${ }_{* * * *}$ Prof. Dr., Marmara Üniversitesi, Atatürk Eğitim Fakültesi, Matematik ve Fen Bilimleri Eğitimi Bölümü Prof. Dr. Marmara University, Ataturk Faculty of Education, Mathematics and Science Education ORCID 0000-0003-4298-2623

eaydin@marmara.edu.tr
}

Cite as/ Atıf: Süzük, E. \& Derin, G. \& Aydın, E. (2020). Bir matematik öğretmeninin bilimin doğası hakkındaki görüşleri: bir tekli durum çalışmas1, Turkish Studies - Education, 15(2), 1189-1212. https://dx.doi.org/10.29228/TurkishStudies.39635

Received/Geliş: 07 November/Kasım 2019

Accepted/Kabul: 07 April/Nisan 2020

Copyright $($ INTAC LTD, Turkey

Checked by plagiarism software

Published/Yayın: 30 April/Nisan 2020

CC BY-NC 4.0 
organized by the ministry of education. Moreover, it is important that in-service training programs being organized should have opportunities for teachers to experience NOS transfer and after the in-service traning, teachers' classroom practices should be followed. Another suggestion is that giving mathematics in a historical context by linking it with other fields, especially with physics, can help to understand how mathematical knowledge is formed and to connect mathematics and mathematical activities with the nature of science. Finally, it can be suggested to researchers that to make more students scientifically literate they should study with more teachers across different disciplines to develop teachers' beliefs about the nature of science.

Structured Abstract: Introduction and Aim: Science is the most important part of cultural and social life in this age (National Research Council [NRC], 1996; American Association for the Advancement of Science [AAAS], 1990) where it is more important to know how to use information than to have information. Bringing scientific literate individuals to society is accepted as one of the most important goals of science education (Jenkins, 1997). The nature of science is seen as a facilitator in understanding scientific issues and motivating students' interest in science (McComas, Clough and Almozroa, 1998). Therefore, the nature of science is one of the most important goals of scientific literacy.

The understandings and views of teachers who will teach the nature of science to the students are important because the views of a teacher about the nature of science affect students' ways of communicating and benefiting from science (Aktamış, 2012). Although the nature and teaching of science is often associated with science, NRC (1996) emphasizes that having scientific inquiry skills related to the nature and function of science is essential not only for teaching science but also for mathematics. The basic point of learning science and mathematics is not to understand these disciplines separately, but to focus on scientific literacy (Rutherford \& Ahlgren, 1989 act. Deveci, 2010).

Approaches that combine Science, Technology, Engineering and Mathematics (STEM) fields have been included in the curriculum in recent years to increase students' interest in basic sciences and to increase their workforce in these fields. Therefore, researchers should research not only science teachers but also other field teachers' understanding of the nature of science.

In the related literature, there are many studies conducted with teachers, prospective teachers and students regarding their understanding of the nature of science. However, studies with mathematics teachers on the nature of science are very limited. Moreover, in most studies the data collected with Likert type scales. However, as highlighted above, mathematics teachers should understand how scientists think and behave and convey their understanding to their students.

Private schools try to respond to the demands of students and parents for a qualified education (Subaş1 and Dinler, 2003) and try to increase their market share in the education sector both by following the developments in technology very closely and by making effective use of those developments (Zeybekoğlu, 2008). Moreover, private schools have an important influence on the development of new ideas and practices in education in Turkey (Uygun, 2003).

For these reasons, an experienced mathematics teacher, who works in a private school has been studied as a case. In this context, the aim of the study is to examine the views of a private school mathematics teacher about the nature of science by revealing its cognitive map.

Method: In this study, the views of a mathematics teacher about the nature of science (NOS) were examined in depth by using Views on Nature of Science Questionnaire - Form C"(VNOS-C) questionnaire developed by Abd-El-Khalick(2001). This qualitative study is a single case study with an interpretive paradigm. The participant is a mathematics teacher nicknamed as Mehmet. In data analysis, content analysis was used in four steps (followed by İrez, 2006) and as a result of the analysis, the cognitive map of the participant revealing his views about NOS was obtained.

Results and Discussion: The findings show that Mehmet, who has been teaching mathematics in a private college for 12 years, has some naive views about the nature of science and that he does not have enough accurate knowledge of the concept. This result coincides with the results of the studies of the nature of science conducted with primary and secondary school teachers for about 50 years which said that teachers do not have sufficient concepts of the nature of science (Lederman, 2013). 
First of all, Mehmet thinks that science is measurable, provable and comes from knowledge. Secondly, Mehmet is also aware that technology is a tool. In the relevant literature, there are studies that find the majority of teachers confuse science with technology.

However, Mehmet believes that there is only one universal method in science and that there is a direct correlation between the multiplicity of the number of experiments and observations and the accuracy of information. Moreover, Mehmet thinks that theories can change and theories are influenced by the environment and conditions. In accordance with this study, in the related literature, Aslan, et al., (2009), Turk, Yildirim, et al., (2018) and Gürses, et al., (2005) reported that teachers and prospective teachers believes in scientific knowledge and theories are subject to change. In contrast to this study, Murcia and Schibeci (1999) found that teachers had misconceptions about science and scientific knowledge. However, while defending this view, Mehmet also questions whether there is definite information and thinks that an information cannot be law until it is proved $100 \%$. It is seen that Mehmet had the misconception that there is a hierarchical structure between theory and law. This result is similar to the results of Aslan, et al., (2009) and Abd-El-Khalick and Akerson (2004).

According to another conclusion obtained in this study, Mehmet thinks that scientists can reach different results by using the same data because of different perspectives and mental processes. In the relevant literature, Lederman (2007) and McComas (2003) state that scientists' attitudes, beliefs, prior knowledge and experiences will affect research questions, data collection methods, and the way they interpret data, and emphasize that scientists are not human beings to act objectively.

According to Mehmet, science is influenced by social and cultural values as well as scientific processes paralleling natural processes. Consistent with this result, Timur and Çetin (2018), Buaraphan (2009) and Aikenhead (1987) state that there is a mutual interaction between science and society and that society and cultural values affect the work of scientists. However, there are studies in the relevant literature that neither prospective teachers nor teachers see science as a social phenomenon (Ryan and Aikenhead, 1992) and human cultural activity (McGinn, 1991).

Lastly, Mehmet thinks that scientists use their imagination and creativity in scientific processes and this view is consistent with the results of the related literature. For example, scientists are working on subjects which they are curious about (Çakıcı, 2009) and concepts such as creativity, imagination, dynamism and temporality are closely related to science (Timur and Çetin, 2018).

Suggestions: Some suggestions were made based on the results of the research. First, Mehmet has some naive and insufficient understandings of the nature of science. Mehmet thinks that science is mostly based on experimentation and observation. However, the role of reasoning is more than experiment and observation when science is considered as an effort to reach theories or laws. The production of hypotheses that are the basis of scientific theories is the product of reasoning, creative talent and imagination. Experiments and observations are used in the control (falsification) of inferences obtained from the hypothesis (Günay, 2003). Therefore, in order to develop students' understanding of the nature of science, teachers' perceptions must be developed. In this context, Mehmet's beliefs can only be fulfilled by in-service training since he has not taken any courses related to the nature of science during his university education. It may be suggested that the Ministry of National Education should organize in-service training programs on the nature of science and that private school teachers should be given the right to participate in these in-service trainings.

Furthermore, since in-service training programs are generally organized as courses or seminars, teachers do not have the chance to experience during the training (Kartal et al., 2019). However, it is not enough for teachers to develop their own views and understandings about the nature of science. They also should know how to effectively transfer their developed views to the classroom environment and also should increase their related self-efficacy beliefs. For these reasons, it may be suggested that in-service training programs being organized should have opportunities for teachers to experience NOS transfer. And then it may be recommended teachers' classroom practices should be followed.

Another reason for Mehmet's inadequate beliefs may be result-oriented trainings, textbooks offering memorized practices and widespread use of false beliefs (Aslan, et al.,, 2009; İrez, 2008; Aikenhead and Ryan, 1992). In traditional mathematics education, mathematical terms are often presented as timeless beings that are not connected to nature or the empirical world, and as ideal objects outside of space and time, and the theories about them as eternal facts (Kjeldsen and Lützen 2015). However, giving mathematics in a historical context 
by linking it with other fields, especially with physics, can help to understand how mathematical knowledge is formed and to connect mathematics and mathematical activities with the nature of science. Finally, it can be suggested to researchers that to make more students scientifically literate they should study with more teachers across different disciplines to develop teachers' beliefs about the nature of science.

Keywords: Mathematics And Science Education, Nature Of Science, Ordinary Teacher, Scientific Literacy, Cognitive Map.

Öz: $\mathrm{Bu}$ çalışmada tipik bir matematik öğretmeninin bilimin doğası hakkındaki inancının derinlemesine incelenmesi amaçlanmıştır. Katılımcı lisans eğitiminde bilim tarihi veya bilimin doğası üzerine herhangi bir ders almamıştır. Katılımcının görüşlerinin belirlemek amacıyla veriler Abd-El-Khalick ve arkadaşları (2001) tarafından geliştirilen "Bilimin Doğası Hakkındaki Görüşler Anketi, C Formu” (VNOS-C) anketi kullanılarak oluşturulan 10 soruluk yarı-yapılandırılmış görüşme formu ile toplanmıştır. Görüşmeye başlamadan önce katılımcıya, araştırmanın herhangi bir anında hiçbir sebep göstermeksizin araştırmadan ayrılabileceği, çalışmada kimliğini ortaya çıkaracak herhangi bir unsurun olmayacağı, çalışma boyunca isminin kullanılmayacağı, görüşme kayıtlarının araştırmacı haricinde kimse tarafından görülmeyeceği, verilerin kimsenin ulaşamayacağı şekilde muhafaza edilip çalışma bittikten sonra imha edileceği, görüşme kayıtları transkript edildikten sonra kendisine gönderilip onayı alındıktan sonra kullanılacağı belirtilmiş ve katılımcının yazılı onayı alındıktan sonra görüşmeler yapılmıştır. Katılımcı ile görüşmeler 2018 yılı Nisan ayı içerisinde haftada bir kez olmak üzere $4 \mathrm{kez}$ yapılmıştır. Elde edilen verilerin içerik analizinden elde edilen temalar ışığında katılımcının bilimin doğası hakkındaki görüşlerini ortaya koyan bir bilişsel haritası yapılmıştır. Elde edilen bulgulara göre, katılımcı bilimin doğası ile ilgili olarak bilimde evrensel bir yöntem olduğu, deney ve gözlem sayısının çokluğu ile bilginin doğruluğu arasında doğru orantı olduğu, teorinin hipotezin ispatlanmış hali olduğu ve teori ile kanun arasında hiyerarşik bir yapı olduğu gibi kavram yanılgılarına sahiptir. Buna karşın katılımcı, bilimin ölçülebilir ve ispatlanabilir olduğunu, teknolojinin bilim için bir araç olduğunu, teorilerin değişebileceğini, bilim insanlarının aynı veriyi kullanarak farklı sonuçlara ulaşabileceğini, bilimin sosyal ve kültürel değerlerden etkilendiğini ve bilim insanlarının hayal güçlerini ve yaratıcılıklarını kullandığını düşünmektedir. Bu bulgular 1şığında özel okullarda çalışan öğretmenlerin de milli eğitim bakanlığının düzenlediği hizmet içi eğitimlere katılması sağlanarak bilimin doğası hakkındaki kavram yanılgılarını gidermek üzere eğitim verilebilir. Ancak düzenlenecek hizmet içi eğitim programlarında öğretmenlere deneyimleme firsatları verilmesi ve devamında öğretmenlerin sınıf içi uygulamalarının da takip edilmesi önemlidir. Bunun yanında matematiğin tarihsel bir bağlam içerisinde diğer alanlarla özellikle fizik ile bağlantı kurularak verilmesi matematiksel bilginin nasıl oluştuğunun anlaşılmasını ve matematiğin ve matematik ile ilgili etkinliklerin bilimin doğası ile ilişkilendirilmesini sağlayabilir. Yine, matematiğin tarihsel bir bağlam içerisinde diğer alanlarla özellikle fizik ile bağlantı kurularak verilmesi matematiksel bilginin nasıl oluştuğunun anlaşılmasını ve matematiğin ve matematik ile ilgili etkinliklerin bilimin doğası ile ilişkilendirilmesini sağlayabilir. Son olarak, bilimsel okuryazar öğrenciler yetiştirmek için farklı disiplinler de dâhil olmak üzere daha çok öğretmen ile çalışma yapılması ve böylece öğretmenlerin bilimin doğasına ilişkin inanışlarının belirlenmesi ve geliştirilmesi araştırmacılara önerilebilir.

Anahtar Kelimeler: Matematik Ve Fen Eğitimi, Bilimin Doğası, Matematik Öğretmeni, Bilimsel Okuryazarlık, Bilişsel Harita.

\section{Giriş}

Bilgiye sahip olmaktan ziyade bilgiyi kullanmayı bilmenin daha önemli olduğu bu çağımızda ( National Research Council [NRC], 1996; American Association for the Advancement of Science [AAAS], 1990) bilim artık kültürel ve sosyal hayatın en önemli parçası durumundadır. Günümüzde bilimsel okuryazar bireylerin oluşturduğu bir toplum oluşturmak dünyanın pek çok ülkesinde bir öncelik haline gelmiştir. Hatta Ekonomik İşbirliği ve Kalkınma Örgütü (OECD) Uluslararası Öğrenci Değerlendirme Programı (PISA) ile öğrencilerin fen içeriğini anlamalarından ziyade, bilimsel okuryazarlıklarını ölçmekte ve değerlendirmektedir (OECD, 2006; 2013). Buna bağlı olarak yukarıda bahsedilen niteliklere sahip bilimsel okuryazar bireyleri topluma kazandırmak fen bilimleri eğitiminin en önemli amaçlarından birisi olarak kabul edilmektedir (Jenkins, 1997). Bilimsel 
okuryazar bir bireyin sahip olması gereken temel bilgi, beceri ve tutumların neler olması gerektiği konusunda alan yazında yoğun tartışmalar vardır. Bu tartışmaların varlığı bilimsel okuryazarlığın pek çok alandan beslenen bir farkındalık olduğunu göstermektedir. Bilimsel okuryazar bir bireyden beklenen en önemli özellik bilim ve bilimsel bilginin doğası konusunda bilinçli olmasıdır (Hurd, 1998). Bilimin doğasını (NOS) anlamak bilimsel okuryazarlığın gelişmesi için önemli bir şarttır (Shamos, 1995; Khishfe ve Lederman, 2006). Ayrıca ilgili alan yazında bilimin doğası bilimsel konuların anlaşılmasında bir kolaylaştırıcı ve ögrencilerin bilime ilgisini motive edici bir unsur olarak görülmektedir (McComas, Clough ve Almozroa, 1998). Bu yüzden bilimin doğasının öğretim sürecinde yer alması bilimsel okuryazarlığın en önemli hedeflerinden birisi olarak ortaya çıkmıştır.

Yukarıda verilen bilimsel okuryazar bir bireyde olması gereken özellikler incelendiğinde, bu özelliklerin gelecek neslin yeni sanayi evresi olan endüstri 4.0 toplumunda başarılı olması için gerekli sayılan 21. yüzyıl becerileri ile örtüştüğü görülmektedir (Association for Career and Technical Education, National Association of State Directors of Career Technical Education Consortium and Partnership for 21st Century Skills, 2010; Wagner, 2008, Bybee, 2010; Windschitl, 2009). Başta OECD olmak üzere ABD, Japonya, Kanada, Almanya, Finlandiya gibi birçok ülke daha çok gelişmek ve zenginleşmek için öğrencilerine 21. yüzyıl becerilerinin kazandırılmasını hedef olarak belirlemektedir (Demir, 2018). Ülkemizde de bilimsel okuryazarlık ve 21. yüzy1l becerilerine sahip bireyler yetiştirme amacı öğretim programlarında da kendine yer edinmektedir (MEB, 2013, 2017a).

Öğrencilerin bilim hakkındaki görüşlerini geliştirmek ve dolayısıyla toplumda bilimsel okuryazarlığ yaygınlaştırmak fen bilimleri eğitimcileri tarafından geniş anlamda toplumsal ve dar anlamda pedagojik açıdan önemli bir hedef haline getirilmiştir. Pedagojik açıdan, bilimin doğasını anlamak fen eğitimi sürecinde öğrencilere olumlu katkılar sağlama potansiyeline sahiptir (Lederman, 1992; Driver vd,, 1996). Bilimin doğası hakkında tutarlı bir anlayışa sahip olmanın fen bilimlerinde kavramsal öğrenmeyi desteklemektedir (Driver vd,, 1996; Tsai, 1998).

Bilimin doğasını öğrencilere öğretecek olan öğretmenlerin bilimin doğası hakkındaki anlayışları ve görüşleri önemlidir çünkü bir öğretmenin, bilimin doğası ile ilgili görüşleri, öğrencilerin bilim ile iletişim kurma ve bilimden fayda sağlama yollarını etkilemektedir (Aktamış, 2012). Bilimin doğası ve öğretimi genellikle fen bilimleri ile ilişkilendirilse de NRC (1996), bilimin doğası ve işlevi ile ilgili bilimsel sorgulama yeteneğine sahip olmanın sadece fen değil matematik öğretimi için de şart olduğunu vurgulamaktadır. Fen ve matematiği öğrenmenin temel noktası bu disiplinleri ayrı ayrı anlamak değil, bilimsel okuryazarlığa odaklanmaktır (Rutherford ve Ahlgren, 1989 akt. Deveci, 2010). Fen bilimleri ve matematik diğer disiplinlere göre kıyaslandığında bilimin doğasının öğretiminde en önemli iki disiplin olarak görülmesine (Cavus vd., 2011) rağmen fen ve matematik arasındaki ilişki göz ardı edilmekte ve bilimin doğası genellikle sadece fen bilimleri bağlamında ele alınmaktadır. Hâlbuki bilim tarihi incelendiğinde, Leonardo da Vinci matematiğin deneysel bilimde önemli olduğu, bu teori ve pratiğin birbiriyle ilişkilendirilmesi gerektiğini ve pratik yapılmayan teorinin anlamsız ve teorik yapılmayan pratiğin zayıf ve sonuçsuz kalacağı görüşünü dile getirmektedir (Yıldırım, 2008). Yine, bilim ilginç ve gerçek dünya ile ilişkili problemler yaratarak matematiği desteklerken, matematik te bilimi sayllar, semboller ve grafikler gibi matematiksel araçlarıyla desteklemektedir (Moscovici ve Newton, 2006; AAAS, 2001; McComas ve Wang, 1998). Bilime çıkarımda (öndeyi) bulunma gücü veren matematik (Günay, 2003) bilim için sadece bir veri analizi aracı değil aynı zamanda bir düşünme ve kritik etme aracıdır (Wong ve Dillon, 2019). Matematik ve fen bilimleri birbirini tamamlayan iki disiplin olarak ele alınmazsa ve özellikle fen derslerinde matematiksel formlar ve temsillerin kullanılmasından kaçınılması, öğrencilerin bilimin doğası hakkında yanlış anlamlar kazanmasına neden olabilir (Osborne, 2004). Ancak, uluslararası fen eğitimi dergilerinde fen ve matematiğin beraber olduğu çalışmalara ve benzer şekilde matematik eğitimi alan yazınında da fen ve matematik ilişkisine çok az yer verilmektedir (Orton ve Roper, 2000; Wong ve Dillon, 2019). Hâlbuki fen bilgisi öğretmenlerinin yanı sıra matematik öğretmenleri 
de bilim insanlarının nasıl düşündüklerini ve davrandıklarını anlamalı ve öğrencilerine aktarabilmelidir (Aktamış, 2012).

Diğer taraftan, son yıllarda temel bilimlere (fizik, kimya, biyoloji ve matematik) olan ilginin azalması tüm dünyada olduğu gibi ülkemizde de karşımıza çıkan bir problemdir (Süzük ve OganBekiroğlu, 2017). Öğrencilerin temel bilimlere olan ilgisini arttırmak ve bu alanlardaki iş gücünü arttırmak için Fen, Teknoloji, Mühendislik ve Matematik (FETEMM) alanlarını bir araya getiren yaklaşımlar öğretim programlarında yerini almıştır. 2017 yılında yayımlanan (MEB, 2017b) ve 2018 yılında güncellenen (MEB, 2018a) öğretim programlarında bilimsel düşünme odaklı bir yaklaşımla FETEMM ve girişimcilik alanlarının yer aldığı görülmektedir. İlköğretim matematik programında ise matematiksel yetkinlik ve bilim/teknolojide temel yetkinliklerin öğrencilere kazandırılması amaçlandığı belirtilmektedir. (MEB, 2018b). Günümüz öğretim programlarında disiplinler arası yaklaşımla öğretmen adaylarının ve öğretmenlerin bilimin doğası konusundaki bilgi ve kavrayışlarının geliştirilmesi gerekmektedir (Doğanay, Demircioğlu ve Yeşilpınar, 2014). Bu nedenle, artık sadece fen bilimleri öğretmenlerinin değil, aynı zamanda diğer alan öğretmenlerinin de bilimin doğası anlayışları araştırılmalı ve geliştirilmelidir (Wong, Firestone, Ronduen ve Bang, 2016). İlgili alan yazında bilimin doğası anlayışları ile ilgili olarak öğretmen, öğretmen adayı ve öğrencilerle yapılmış birçok çalışma bulunmaktadır ( Rubba ve Harkness, 1993; Mellado, 1998; Abd-El-Khalick vd., 1998; Gücüm, 2000; Moss, 2001; Akerson ve Abd-El-Khalick, 2003; Gürses vd., 2005; Lederman, 2007; Kenar, 2008; Çavuş, 2010; Bilen, 2012; Çalışkan vd., 2015; Yüce ve Önel, 2015; Dikmentepe ve Yakar, 2016; Dursun ve Özmen, 2018). Bu çalışmalar genellikle fen bilimleri (fizik, kimya ve biyoloji) öğrenci ve öğretmen adayları ile yapılmış çalışmalar olup, genel sonuç öğrenci ve öğretmenlerin bilim doğasına yönelik görüşlerinin eksiklik ve yanlışlıklar içerdiği şeklindedir. Bunların yanında Gürel (2002) resim öğretmen adayları, Tufan (2007) müzik öğretmen adayları, Kızılcık vd. (2007 sözel bölüm öğretmen adayları, Tatar vd. (2011) sınıf öğretmeni adayları, Saraç (2012) sınıf öğretmeni adayları ve sınıf öğretmenleri, Çınar ve Köksal (2013) sosyal bilgiler öğretmen adayları, Çelik ve Karataş (2016) fen bilimleri ve matematik öğretmen adayları, Türk vd. (2018) okul öncesi öğretmenleri ve Akgün ve Özenoğlu (2018) sınıf öğretmenleri ile çalışmıştır. Farklı gruplar ile yapılan bu çalışmalarda da öğretmen adaylarının ve öğretmenlerin bilim doğasına yönelik naif (yetersiz ve eksik) görüşlere sahip olduğu tespit edilmiştir.

Ancak ilgili alan yazında bilimin doğasına ilişkin matematik öğretmenleri ile yapılan çalışmalar çok kısıtlıdır. Yine yapılan çalışmalarda genellikle likert tipi ölçekler ile veriler toplanmıştır. Hâlbuki yukarıda da vurgulandığı gibi matematik öğretmenleri de bilim insanlarının nasıl düşündüklerini ve davrandıklarını anlamalı ve bu anlayışlarını öğrencilerine aktarabilmelidir. Ülkemizde ilköğretim matematik öğretmenliği programlarında 2007 yılında yapılan (YÖK, 2020) güncellemede bilim tarihi dersi lisans programına eklenmiş ve 2008 yılından itibaren birinci siniflarda uygulamaya koyulmuştur.

Özel okullar gerek teknolojideki gelişmeleri çok yakından takip ederek ve bu gelişmelerden etkili bir şekilde yararlanarak teknoloji ile eğitim süreçlerini en iyi şekilde birleştirerek öğrenci ve velilerin kaliteli eğitim ve öğretim taleplerine cevap vermeye (Subaşı ve Dinler, 2003) ve eğitim sektöründeki pazar paylarını arttırmaya çalışmaktadırlar (Zeybekoğlu, 2008). Yine, Türkiye'de eğitimde yeni fikir ve uygulamaların gelişmesinde özel okulların önemli etkisi olmaktadır (Uygun, 2003). Günümüzde de okulların bilgi ve iletişim teknolojilerine sahipliğine bakıldığında iyi say1labilecek durumda olduğu görülmektedir. Özel okullar bu konuda da öncü bir rol üstlenmektedir (Seferoğlu, 2015). Bu nedenle devlet okullarına göre yeniliklere daha açık, teknolojiyi yakından takip eden, eğitim ve öğretimin kalitesi için ulusal ve uluslararası rekabetin yoğun olarak yaşandığı özel bir okulda çalışan deneyimli bir matematik öğretmeni tekli bir durum olarak belirlenmiştir. 
Bu bağlamda, bu çalışmada ilköğretim matematik öğretmenliği 2007 müfredatı uygulamaya girmeden önce mezun olmuş bir özel okul matematik öğretmeninin bilimin doğası hakkındaki görüşlerini bilişsel haritası ortaya konularak, derinlemesine incelemek amaçlanmıştır.

\section{Kavramsal Çerçeve}

Bilimin doğasının herkesin üzerinde anlaştığı bir tanımı olmamakla birlikte, bilmenin bir yolu olarak bilim, bilimin epistemolojisi ve sosyolojisi veya bilimsel bilgi gelişimine özgü inanç ve değerler anlamında kullanılmaktadır (Lederman, 1992; Lederman, Lederman ve Antink, 2013). Bilimin kendisi gibi, bilimin doğasına ilişkin algı ve anlayışlar da gelişmekte ve farklılaşmaktadır (Suchting, 1995; Turgut vd., 2010). Bu nedenle araştırmacılar bilimin doğasının tanımından ziyade özelliklerinin ne olması gerektiği üzerinde çalışmalar yapmaktadır (Lederman, 1992; DeBoer, 2000).

Abd-El-Khalick vd. (1998), çalışmasında bilimin doğasının boyutlarını; bilimsel bilginin değişebilir, olgusal ve öznel olması, çıkarım, hayal gücü ve yaratıcılık içermesi, sosyal ve kültürel olarak yapılandırılması olarak belirtmişlerdir. Lederman (2007) ise bilimin doğasının öğrencilerin anlaması gereken yedi bileşenini tanımlamıştır. Öncelikle, öğrenciler çıkarımlar ile gözlemler arasındaki farkı tanımalıdır. İkincisi, öğrenciler bilimsel bir yasa ile bilimsel teori arasındaki açıklamayı tanımalı ve her iki bilimsel bilginin de bilim alanında değerli olduğunu anlamalıdır. Üçüncüsü, bilimsel bilgi, olguların gözlemlerine, insan yaratıcılı̆̆ına ve hayal gücüne dayanır. Dördüncüsü, bilimsel bilgi inançlar, önceki bilgiler, hazırlıklar, deneyimler ve beklentilerden etkilenir. Bilimsel bilgi aynı zamanda teori yüklü ve bireye özneldir. NOS hakkında öğrencilerinin bilmesi gereken beșinci husus, bilimin "sosyal yapı, güç yapıları, siyaset, sosyoekonomik faktörler, felsefe ve din" gibi faktörlerden etkilendiği sosyo-kültürel bağlamlar içine yerleştirilmiş olmasıdır. Altıncı, bilimsel bilgi mutlak değildir. Bilimsel teoriler, yasalar ve gerçekler, yeni kanıtlar keşfedildikçe değişebilir. Yedincisi, NOS, bilimsel araştırma veya bilimsel süreçlerle eşanlamlı değildir.

İlgili alan yazında bilimin doğası özellikleri ile uyumlu olmayan görüşler kavram yanılgısı (mit) olarak isimlendirilmektedir (McComas, 1998). McComas (1998) çalışmasında 15 tane mit belirlemiştir. Bunlardan bazıları hipotezlerin teoriye ve teorinin de kanuna dönüşmesi şeklinde bir hiyerarşinin olması, bilimsel yasaların ve benzer şekilde elde edilen bilimsel bilginin kesinliği, hipotezin eğitimli bir bilim insanı tarafından yapılan tahmin olması, genel ve evrensel bir bilimsel metodun olması, dikkatlice bir araya getirilen kanıtların kesin bilgiyle neticelenmesi, bilim ve bilimsel yöntemlerin kesin kanıt sağlaması, bilimin yaratıcılıktan ziyade bilimsel yöntemin ile yapılması, bilim tüm sorulara cevap verebilmesi, bilim insanlarının nesnel olması, deneylerin bilimsel bilginin elde edilmesinde en temel yol olması, yeni bilimsel bilginin hemen kabul görmesi, bilimsel modellerin gerçeği temsil etmesi, bilim ve teknolojinin aynı olması ve bilimin tek başına yapılan bir uğraş olması mitleridir.

\section{Yöntem}

Bu nitel çalışma yorumlayıcı paradigmaya sahip bir tekli durum çalışmasıdır. Pozitivist paradigmaya alternatif olarak yükselmeye başlayan yorumlayıcı paradigmanın kökenleri yaklaşık yirminci yüzyılın başlarına dayanmaktadır. Yorumlayııı paradigmada çalışılan olay ya da olgulara yönelik tek doğru ya da tek gerçeklik yoktur. Çünkü her şey birbiriyle iç içe ve birbiriyle ilişkilidir. Araştırmanın deseni olan tekli durum çalışması ise "nasıl" ve "niçin" sorularını temele alan güncel bir olguyu ya da olayı kendi gerçek yaşam çerçevesi içerisinde derinlemesine inceleyen bir nitel araştırma desenidir (Balc1, 2011; Yıldırım ve Şimșek, 2013). Tekli durum çalışması öznel, karmaşık ve işlevsel bir durumun hikâyesini anlama amacıyla derinlemesine bir araştırmadır (Stake, 1995). Bu çalışmada da deneyimli bir özel okul öğretmeninin bilimin doğası hakkındaki inanışları nitel araştırma sürecinde tekli durum çalışması ile ortaya konulmuştur. Bu çalışma ile genel bir teori üretmek veya elde edilen bulguların bir evrene genellenmesi amaçlanmamaktadır. Çalışmanın amacı 
deneyimli bir özel okul matematik öğretmeninin bilimin doğası hakkındaki görüşlerini bilişsel haritasını ortaya çıkararak derinlemesine öğrenmektir.

\section{Katılımcı}

Bir evrende olması muhtemel olan farklılıkları, çeşitlilikleri ve zenginlikleri inceleyerek bütüncül bir bakış ortaya koymak isteyen nitel araştırmalarda (Goetz ve LeCompte, 1984) çalışılan konunun derinlemesine incelenmesi ihtiyac1 ve elde edilecek olan zengin verinin analiz edilmesindeki güçlüklerden dolayı örneklemin sınırlı tutulması ihtiyacı ortaya çıkmıştır (Yıldırım ve Şimşek, 2013). Bu ihtiyaca bağlı olarak nitel araştırma geleneği içinde ortaya çıkan "amaçlı örnekleme" yöntemleri (Yıldırım ve Şimşek, 2013), zengin verinin derinlemesine çalışılmasına olanak vermektedir (Patton, 1987).

$\mathrm{Bu}$ araştırmanın katılımcısı amaçlı örnekleme yöntemlerinden olan kritik durum örneklemesi (Patton, 1987) ile belirlenen Mehmet olarak isimlendirilmiş halen özel bir kolejde öğretmenlik yapmakta olan bir matematik öğretmenidir. Katılımcı belirlenirken çalışma için izin verecek bir özel ilkokul ve çalışmaya katılmaya gönüllü olacak deneyimli matematik öğretmenleri araştırılmış ve araştırmanın katılımcısı belirlenmiştir (Yıldırım ve Şimşek, 2013). Katılımcı öğretmen belirlenirken öğretmenlerin bilim felsefesi, bilimin doğası veya bilim tarihine yönelik bir ders almadığı araştırılmış ve İstanbul'daki bir devlet üniversitesinden 2006 yılında mezun olan Mehmet Bey belirlenen şartlara sahip ve araştırmaya katılım için gönüllü olduğu için katılımcı olarak seçilmiştir. 34 yaşında ve 12 yıllık deneyime sahip bir öğretmen olan Mehmet, fizik öğretmenliğini okumak istemesine rağmen, atanama sorunu yaşamamak için matematik öğretmenliği bölümünü tercih etmiş ve Marmara Üniversitesi İlköğretim Matematik Öğretmenliğini kazanarak İstanbul'a gelmiştir. etmektedir:

Mehmet fiziğe olan ilgisini ve matematik öğretmenliğini seçme nedenlerini şu şekilde ifade

“...Aslında benim daha çok keyif aldığım ve mutlu olduğum branş fizik branşıydı. Yani oradaki mekanik şeyler, hesaplamalar, böyle hani insanların günlük hayatta sıradanlaşmış şeyleri ben biraz daha bilgi boyutunda öğrenmek hoşuma gidiyordu. Yani bir araba nasıl çalışıyor derken oradaki dönel sistemler, motorlar, işte dişli çarklar ya da işte mancınık bunları hani bilmek hoşuma gidiyordu. Yani fizik aslında daha çok istiyordum. Tabi bu da sayısala yatkınlığım olduğunu gösteriyor. Ama sonra o süreçte mezun olacağım yıldan bir beş altı yıl boyunca fizik öğretmeni ataması olmayacağı ifade edildiği için o yüzden matematik tercihim olmuştu..."

Öğrencilik hayatı boyunca bilim felsefesi, bilimin doğası veya bilim tarihine yönelik herhangi bir ders almayan Mehmet, mezun olduktan sonra İstanbul'da özel bir kolejde matematik öğretmenliğine başlamış ve halen aynı kolejde öğretmenlik yapmaktadır.

\section{Verilerin Toplanması}

Çevre, süreç veya algilarla ilgili olmak üzere genellikle üç tür veri toplanan nitel bir araştırmada (Goetz ve LeCompte, 1984) veriler yaygın olarak görüşme, gözlem ve doküman analizi ile toplanmaktadır (Yıldırım ve Şimşek, 2013). Katılımcıların duygularını, bakış açılarını, deneyimlerini ve düşüncelerini ortaya koyan oldukça kuvvetli bir veri toplama yöntemi olan görüşme yönteminin (Bogdan ve Biklen, 1992), beceri, beceri, duyarlık, yoğunlaşma, anlayış, zihinsel uyanıklık, öngörü ve disiplin gibi birçok boyutu vardır ve bu boyutlarıyla görüşme hem sanat hem de bilimdir (Patton, 1987). İlgili alan yazında genellikle yapılandırılmış ve yapılandırılmamış görüşme olmak üzere iki tür görüşme çeşidi kullanılmaktadır (Stewart ve Cash, 1985; Chadwick vd., 1984; akt., Yıldırım ve Şimşek, 2013). Yarı yapılandırılmış görüşmeler araştırmacının önceden hazırlanan konuya bağlı kalmasını sağlamanın yanı sıra araştırmacıya görüşme sürecinde daha ayrıntılı bilgi elde etmek için ekstra soru sorma özgürlüğü de vermektedir (Büyüköztürk vd., 2013). 
Bu çalışmada katılımcının bilimin doğası hakkındaki görüşlerini derinlemesine incelemek; bunu yaparken de ilgili konudan çok sapmamak ve dağılmamak için yarı yapılandırılmış görüşme ile veriler toplanmıştır. Katılımcı ile yapılan görüşmeler 2018 yılı Nisan ayı içerisinde haftada bir kez olmak üzere 4 kez yapılmıştır. Görüşmeye başlamadan önce katılımcıya, araştırmanın herhangi bir anında hiçbir sebep göstermeksizin araştırmadan ayrılabileceği, çalışmada kimliğini ortaya çıkaracak herhangi bir unsurun olmayacağı, çalışma boyunca isminin kullanılmayacağı, görüşme kayıtlarının araştırmacı haricinde kimse tarafından görülmeyeceği, verilerin kimsenin ulaşamayacağ 1 şekilde muhafaza edilip çalışma bittikten sonra imha edileceği, görüşme kayıtları transkript edildikten sonra kendisine gönderilip onayı alındıktan sonra kullanılacağı belirtilmiştir. Ayrıca görüşmeden önce katılımcıdan izin alınarak görüşme ses kaydı şeklinde kaydedilmiştir. Görüşmenin verimliliği için sessiz ve dikkat dağıtıcı nesnelerden olabildiğince arındırılmış baş başa kalınabilecek uygun ortam oluşturulmuştur. Mehmet'le bilimin doğasına ilişkin düşüncelerini öğrenmek üzere yapılan görüşmenin ilk dakikaları hem Mehmet'i rahatlatmak hem de mülakata 1sındırmak amacıyla kişisel bilgilerinin konuşulmasıyla geçmiş̧ir. Görüşmeler toplamda 4 saat 43 dakika sürmüştür.

\section{Veri Toplama Aracı}

Katılımcının bilim hakkındaki görüşleri Abd-El-Khalick (2001) tarafından geliştirilen VNOS-C (Views on Nature of Science Questionnaire, Form C-Bilimin Doğası üzerine Görüşler Anketi, C Formu) anketi aracılığıyla toplanmıştır. VNOS anketinin orijinal formu Lederman ve O’Malley (1990) tarafindan geliştirilmiş ve yedi açık uçlu soruyu içermektedir. VNOS lise öğrencilerinin bilimin deneysel doğası hakkındaki görüşlerini değerlendirmek amacıyla bireysel görüşmelerin takibi ile bağlantılı olmasında kullanılmıştır (Abd-El-Khalick vd.,„2001). 1998 yılında anket Abd-El-Khalick ve arkadaşları (2001) tarafından ikinci kez geliştirilmiş ve on soruya dayanan son formuna (Form C) modifiye edilmiştir. Orijinal anket kâğıt-kalem aracı olarak geliştirilmiş olmasına rağmen, sorular açık uçlu olduklarından dolayı görüşmelerde kullanım için de uygundur. $\mathrm{Bu}$ sorular yoluyla, bilimin doğasının bazı öğeleri hakkında katılımcının görüşleri toplanmıştır. Görüşmede sorulan öğeler bilimsel yöntem ve bilimsel teorilerin doğası, bilimsel bilginin deneysel doğası, bilimin yaratıc1 ve hayal gücüne dayanan doğası, bilimsel bilginin sübjektif doğası ve bilimsel bilgi üzerindeki sosyal ve kültürel etkileri içermektedir. Bu öğelerin hepsi bir arada ele alındığında bilimin doğasını büyük bir oranda tasvir ettiği ve böylece katılımcının bilimin doğası hakkındaki inançlarının bütün bir resmini ortaya çıkarmada yardım ettiği görülmektedir (İrez, 2006). VNOS-C yazıll olarak uygulanan bir ölçek olmasına rağmen, açik uçlu sorulardan oluşması nedeniyle görüşmelerde de kullanılabilir bir niteliğe sahiptir (Bakanay, 2008). Katılımcıya VNOSC'de yer alan açık uçlu sorular çerçevesinde toplam 11 soru sorulmuştur.

\section{Verilerin Analizi}

$\mathrm{Bu}$ çalışmada nitel veri analizi yaklaşımlarından içerik analizi kullanılmıştır. İçerik analizi toplanan verilerin derinlemesine analiz edilmesini gerektirmekte ve önceden bilinmeyen temaların ve boyutların ortaya çıkarılmasını sağlamaktadır (Yıldırım ve Şimşek, 2013). Nitel veri analizinin standartlaştırılması oldukça zor olmasına rağmen (Strauss, 1987; Coffey ve Atkinson, 1996; akt. Yıldırım ve Şimşek, 2013) yine de nitel veri analizi sürecinin kapsamlı ve sistematik olması gerekmektedir (Coffey ve Atkinson, 1996; akt. Yıldırım ve Şimşek, 2013). Analiz sürecinin kapsamlı ve sistematik olması amacıyla veri analizi için İrez'in (2006) çalışmasından yararlanılmıştır. Buna göre analiz 4 aşamada tamamlanmıştır.

Veri analizine ilk olarak ses kayıt cihazına kaydedilen konuşmaların transkript edilmesiyle başlanmıştır. Elde edilen transkript katılımcı ile paylaşılarak onayı alındıktan sonra analiz sürecine devam edilmiştir. Devam edilen analiz sürecinde ilk olarak veriler kodlanmıştır. Kodlama, verilerdeki sorulara ve bu sorulara katılımcının verdiği cevaplara numara verilerek gerçekleştirilmiştir. Örnek kodlama aşağıdaki gibi yapılmıştır: 
Araştırmacı (Soru 1): Sayın hocam, size göre bilim nedir? Bilim nasıl bir şeydir? Mesela fizik, kimya, biyoloji düşündüğünüzde, bu tarz disiplinlerin felsefe ve din gibi disiplinlerden farkı ne? Bilim nedir?

Katılımcı: (1.1)Bilim deyince aklımda çağrışan ilk şey bilimin daha somut olduğu, hani daha ölçülebilir, gözlenebilir olduğu. (1.2) Ama diğer şeylerin biraz daha hani insanı sanki manevi tarafi ile daha soyut olduğu, manevi tarafiyla ilgili olduğuna dair şeyler ortaya çıkıyor, zihnimde öyle şeyler oluşuyor mesela. (1.3) Hani “Bilim Nedir?” diye matematik alanında ya da diğer alanlarda düşünecek olursak, hani sanki daha ölçülebilir, ispatlanabilir şeyler bilimmiş gibi geliyor insana.

Yukarıda örnek olarak verilen kodlamaya göre katılımcının birinci soruya verdiği cevapta bilgi içeren her bir yapı sırayla numaralandırılmış ve böylece katılımcıya ait $1.1,1.2$ ve 1.3 bilgi cümleleri elde edilmiştir.

Veri analizinin ikinci adımında ilk adımda elde edilen cümleler bilimin doğası boyutlarına göre benzer temalar altında gruplandırılmıştır. Böylece katılımcının bilimin doğasına ilişkin görüşlerini ifade eden cümleleri bir araya getirilmiştir. Ancak bu temalar birbirinden bağımsız olmadığı için katılımcının aynı ifadeleri farklı temalar altında görülmektedir. Bu nedenle analizin üçüncü aşamasında katılımcının bilimin doğasına ilişkin görüşlerini ortaya koyan ifadeleri, farklı cümlelerin aynı ifadede bir araya getirilmesi ile oluşturulmuştur. Bu aşama bir anlamda ikinci adımda elde edilen tüm cümlelerin "veri indirgemesi" ile toparlanması ve özetlenmesi sürecidir.

Veri analizinin son adımı ise elde edilen ifadelerden katılımcının bilişsel haritasının oluşturulmasıdır. Bilişsel haritaların elde edilmesi Novak ve Gowin (1984)'in kavram haritalarını elde etme yöntemi ile benzeşmektedir. Ancak kavram haritaları kavramlar arasındaki ilişkileri önermeler biçiminde ifade etmekte iken bilişsel haritalar bir katılımcı ile yapılan görüşmeden elde bir metin parçasını sorgulamaktadır (Miles ve Huberman, 1994). Bu sayede katılımcının çalışmadaki tüm düşüncelerinin ayrıntılı olarak kavramsal düzeyde bir şemada görülmesi ve okuyucuya kolaylık sağlanması amaçlanmaktadır. Bir önceki adımda oluşturulan katılımcının ifadeleri ve cümleleri, onun bilişsel haritasını oluşturmak için kullanılmıştır. Bilişsel haritasının oluşturulması, bilgilerin dikkatli bir analizi, kategoriler içinde bu bilgilerin sınıflandırılması ve aralarındaki ilişkilerin tanımlanmasını gerektirmektedir. Bu aşama tamamlandıktan sonra bilgiler arasındaki ilişkiler ve kavramlar, bir bilişsel harita formunda grafiksel olarak sunulmaktadır (İrez, 2006).

\section{Bulgular ve Yorum}

Bu bölümde verilerin analizi sonucu elde edilen bulgulara yer verilmiştir.

\section{Katılımcının Bilim Doğası ile İlgili Görüşleri ve İlgili Temaları}

Katılımcının bilimin doğası hakkındaki ifadeleri 9 temada gruplandırılmıştır. Bu temalar; (1) bilimin tanımı, (2) bilimde deneysellik, (3) bilimsel yöntem, (4) bilimde değişim, (5) bilimsel teori ve kanunlar, (6) bilimde tahmin ve teorik kabuller, (7) bilimde objektiflik-subjektiflik, (8) bilimtoplum ve (9) bilimde hayal gücü ve yaratıcılık şeklindedir. Verilen bu başlıklar bilimin doğasının bileşenlerine yönelik olduğu için hepsi birbirini tamamlayıcı biçimdedir. Birbirinden bağımsız olmadıkları için katılımcının düşünceleri birden fazla başlıkta yer alabilmektedir. Katılımcının görüşlerinin kategorileştirilmesi sonucunda ortaya çıkan 9 başlık ve ilgili kodlamalar Tablo 1'de gösterilmiştir: 


\begin{tabular}{|c|c|}
\hline \multicolumn{2}{|r|}{ Tablo 1: Veri İndirgemesi Örneği } \\
\hline Tema & Kodlamalar \\
\hline \multirow{6}{*}{ Bilimin Tanımı } & $1.1,2,3,4,5,6,7,8,9,10,11,12,13,14,15,16,17,18,19,203.3,4$ \\
\hline & $5.1,9,10,15$ \\
\hline & 8.22 \\
\hline & 9.3 \\
\hline & $10.5,7$ \\
\hline & $11.1,9,15,22,25$ \\
\hline \multirow{6}{*}{ Bilimde Deneysellik } & $1.17,192.1,2,3,4,5,6,7,8,10,11,12,13,14,15,17,18,19,20,21$ \\
\hline & $3.5,8,9,10,19$ \\
\hline & $7.4,8$ \\
\hline & $8.9,20$ \\
\hline & 10.7 \\
\hline & 11.6 \\
\hline \multirow{9}{*}{ Bilimsel Yöntem } & $1.15,17,18,19,20$ \\
\hline & $2.2,3,4,7,17,20$ \\
\hline & $3.1,2,4,5$ \\
\hline & $5.8,9,10,11,15$ \\
\hline & $7.4,8,9,10$ \\
\hline & $8.2,4,7,9,20$ \\
\hline & $9.2,3,7,8$ \\
\hline & $10.7,8$ \\
\hline & $11.1,6,9,11,15,16,17,19,23$ \\
\hline \multirow{4}{*}{ Bilimde Değişim } & $2.2,8,10,17$ \\
\hline & $5.1,2,5,8,9,10,11,12,14,15,18,19$ \\
\hline & $7.1,4,7,9,10$ \\
\hline & 11.19 \\
\hline \multirow{6}{*}{ Bilimsel Teori ve Kanunlar } & $2.7,18$ \\
\hline & $4.1,2,3$ \\
\hline & $5.1,18,19$ \\
\hline & $6.1,3,4,5,6$ \\
\hline & $7.5,7,9,11$ \\
\hline & $11.6,15$ \\
\hline \multirow{7}{*}{$\begin{array}{l}\text { Bilimde Tahmin ve Teorik } \\
\text { Kabuller }\end{array}$} & 1.20 \\
\hline & $2.1,2,6,7,14$ \\
\hline & $7.1,2,3,4,5,7,9,10,11$ \\
\hline & $8.1,2,4,7,9,18,20,22$ \\
\hline & $9.3,7$ \\
\hline & $10.5,7,8$ \\
\hline & 11.6 \\
\hline \multirow{7}{*}{$\begin{array}{l}\text { Bilimin Objektifliği- } \\
\text { Subjektifliği }\end{array}$} & $1.9,10,12,13,14,15,16,18$ \\
\hline & $2.2,5,6$ \\
\hline & 5.15 \\
\hline & 8.1 \\
\hline & $9.1,2,3,4,5,6,7,8$ \\
\hline & $10.1,2,4,7,8$ \\
\hline & $11.1,13,16,17,19$ \\
\hline \multirow{5}{*}{ Bilim-Toplum } & 2.18 \\
\hline & $3.2,4,5$ \\
\hline & $5.6,8,9,10,19$ \\
\hline & $10.1,2,4,5,7,8$ \\
\hline & $11.1,7,8,9,13,17,19$ \\
\hline Bilimde Hayal Gücü ve & $7.5,10$ \\
\hline Yaratıcılık & $11.1,5,6,7,8,9,11,12,13,16,17,19,21,25,27$ \\
\hline
\end{tabular}


Katılımcının bilimin doğasına ilişkin görüşlerini ortaya koyan ifadelerinden elde edilen temalardan bilişsel haritasının oluşturulabilmesi için öncelikle veri indirgemesi” yapılmıştır.

Veri indirgeme sürecinin bir örneği aşağıdaki Tablo 2'de gösterilmiştir:

Tablo 2: Veri İndirgemesi Örneği

\begin{tabular}{ll}
\hline İndirgenmiş Katılımcı İfadesi & Kodlamalar \\
\hline & 1.20 \\
& 2.14 \\
Bilimde kabulleniş ve yorum vardır. & 5.15 \\
& $8.2,4,7,9,18$ \\
& $9.7,8$ \\
& $10.7,8$ \\
\hline Bilim insanın doğal olarak yaptı̆̆ & $3.2,3,4,5$ \\
şeylere yakındır. & 10.5 \\
\hline Bilimde hayal gücü ve yaratıcılık & 11.15 \\
vardır. & 7.5 \\
\hline Bilim bilgiden gelir. & $7.10,7,8,9,27$ \\
\hline Bilgi ortam ve koşullara göre & 11.22 \\
değişir. & 7.12 \\
\hline & 8.20 \\
Deney ve gözlem birer ispat şeklidir. & 1.17 \\
& 2.7 \\
\hline Teori hipotezin ispatlanmış halidir. & 11.6 \\
\hline Kanun teoriden daha önemlidir. & 6.1 \\
\hline Kanun tüm dünyaca doğruluğu & 6.4 \\
kabul edilmiş, ispatlanmış şeylerdir. & $6.1,3,5,6$ \\
\hline Teoriler ortam ve şartlara göre & 5.14 \\
değişir. & $2.17,18,19,21$ \\
\hline Deney çok tekrarla teoriye yaklaşır. & 8.9 \\
\hline & $7.9,10$ \\
Bilim fiziksel çevreden etkilenir. & $9.4,5$ \\
& $10.1,2,4,7$ \\
\hline Deneyler \%100 doğru sonuç & $11.13,19,21$ \\
\hline vermeyebilir. & 2.10 \\
\hline & 2.2 \\
Bilimde kesin bilgi yoktur. & $5.1,2,15$ \\
& $8.1,2,4,7,11$ \\
\hline
\end{tabular}




\section{Katılımcının Bilim Doğası ile İlgili Bilişsel Haritası}

Bu başlık altında indirgenmiş katılımo ifadeleri kullanılarak elde edilen katılımcının bilişsel haritası sunulmuş (Şekil 1) ve bu bilişsel haritası bağlamında Mehmet'in bilimin doğasına ilişkin görüşleri örnek ifadelerle ortaya konulmuştur.

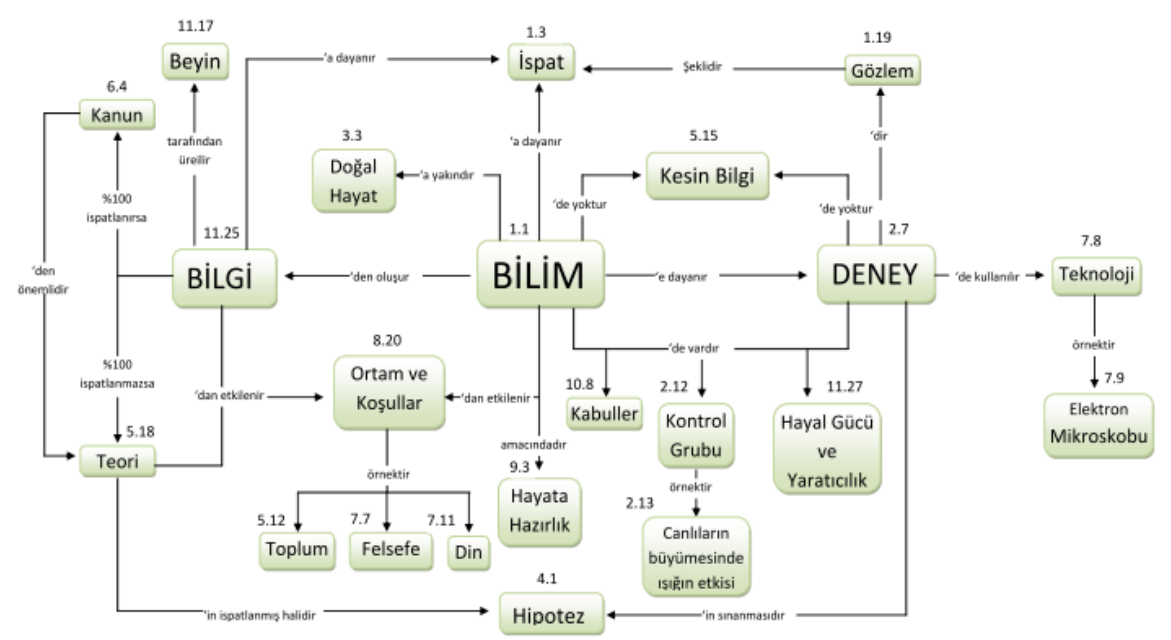

Şekil 1. Mehmet'in Bilimin Doğasına Yönelik Görüşlerini İçeren Bilişsel Haritası

Şekil 1'de verilen bilişsel haritada görülebileceği gibi “Bilim nedir?” sorusuna Mehmet:

(1.3) Hani "Bilim Nedir?" diye matematik alanında ya da diğer alanlarda düşünecek olursak, hani sanki daha ölçülebilir, ispatlanabilir şeyler bilimmiş gibi geliyor insana.

(11.25) İşte bilimin temeli olarak düşünürsek şimdi siz bilim dediğimiz şey bilgiden gelen şey değil mi?

cevaplarını vermiştir. Buna göre Mehmet bilimin ölçülebilir, ispatlanabilir olduğunu ve bilgiden geldiğini düşünmektedir.

İkinci olarak Mehmet alan yazında sıkça karşılaşılan bilim ve teknolojiyi karıştırma yanılgısına (McComas, 1998) sahip değildir. Mehmet teknolojinin bir araç olduğunun farkındadır:

(7.8) Tabi bire bir gözlenmiyor illaki ama mutlaka elektronik ortamlarda, elektron mikroskoplarıyla atomun yapısı inceleniyor.

Bilim insanlarının kullandığı evrensel bir yöntemin olup olmadığı sorusuna bilişsel haritasında da görülebileceği gibi hipotez, deney, teori ve kanun gibi evrensel bir sıralamanın olduğundan bahsetmiştir. Mehmet'in bu soru ile ilgili ifadeleri şu şekildedir:

... mesela ben bir fikir beyan ediyorsam... bunun bir dayanağı olmalı... (3) Hipotez oluşturuyorsunuz... (4)Bunu bir deneyelim o zaman... (21)Dolayısıyla bir deney tabi deney sayısını çoğalttıkça çoğalttıkça sanki doğru sonuca daha çok yaklaşacak gibi diye düşünüyorum.

Yukarıdaki cevaplardan da anlaşılacağı gibi Mehmet'in bilimde evrensel bir yöntemin olduğuna yönelik çok sık rastlanan bir kavram yanılgısına (AAAS, 1990; Abd-El-Khalick ve ark., 2001; McComas, 1998) sahip olduğu görülmektedir. 
Mehmet'e "Deney nedir?" sorusu sorulduğunda bilişsel haritasından da anlaşıldığı üzere deneyi bir gözlem olarak ifade etmiştir. Mehmet'e göre deney hipotezlerin kurulması ve onların çokça sınanarak teoriye ulaşılmasıdır. Ayrıca deneylerde kontrol grubu olduğunu düşünmektedir.

...(1.19) gözlem yapıyoruz... (2.3) Deney, şöyle mesela bir şey, bir öneriniz var ya tez oluşturuyorsunuz. Hipotez oluşturuyorsunuz... Yani diyorsunuz ki bu böyle mi değil mi?... (2.12)Bir kontrol grubu oluşturuyorsunuz, belli şartları sağliyorsunuz... (2.21)Dolayısıyla bir deney tabi deney sayısını çoğalttıkça sanki doğru sonuca daha çok yaklaşacak gibi diye düşünüyorum.

Mehmet yukarıdaki ifadelerinde görüleceği üzere deney ve gözlem sayısının çokluğu ile bilginin doğruluğu arasında doğru orantı kurarak tipik bir kavram yanılgısı sergilemiştir. Ancak yine bilişsel haritasına bakıldığında Mehmet'e göre kesin bilgi veya \%100 doğru bilgi yoktur. Fakat yine mülakat içinde verdiği bilgilere göre bir şeyin bilgi olabilmesi için mutlaka ispatlanması gerekir. Bu durumda anlaşılacağı üzere Mehmet çelişki yaşamaktadır.

(2.10)Tabi burada da deney \%100 doğru sonuç verir mi? sorusu akla gelse de hani \%100 doğru var mı? Bir defa. Belki orada bir sıkıntı var... Bilginin de doğruluğunu ispatlamak için denemem lazım diye düşünüyorum.

Bilimsel bilginin gelişmesi için deneyin şart olup olmadığı sorulduğunda Mehmet'e göre bilimsel bilgi için deney şarttır.

(3. 1)Yani sanki düşündüğünüz zaman kesinlikle gerekir diye düşünüyor insan.

Mehmet'e sorulan diğer bir soru bilimsel teorinin ne olduğudur. Bu soruya alınan cevap bilişsel haritasında da görüleceği gibi bir kavram yanılgısını göstermektedir. Mehmet'e göre teori hipotezin ispatlanmış halidir. Ancak Mehmet burada da bir çelişki yaşamaktadır. Şöyle ki teorinin hipotezin ispatlanmış hali olduğunu düşünmekle beraber bu ispatın \%100 doğru olmadığ1, şüphelerin olduğunu düşünmektedir. Çünkü bilişsel haritasından da görüleceği gibi Mehmet'e göre bilgi eğer \%100 ispatlanırsa kanun olur. Dolayısıyla bir teori için bir takım şüpheler mutlaka vardır. Aşağıda Mehmet'in bazı ifadeleri örnek olarak verilmiştir.

(1)Bilimsel teori hani hipotezin ispatlanmış hali diye düşünürsek hani bir hipotez var elimizde, hipotezimizi denedik, ispatladık ama (2)şöyle bir şey de var ispatladığım zaman hani teori olarak, yasa olmadığ 1 için teori olarak kaldığ 1 için ispatlandı ama yine de acabaları, acaba tarafi bir miktar da olsa var. (3)Tam olarak doğruluğu ispatlanmamış. Ya da belki kontrollü deney yapacak bir ortam oluşmamış, biraz daha soyut kalmış, tam olarak ispatlanamamış. İspatlanmış ama \%100 diyecek kadar da değil.

Mehmet teorilerin değişebileceğini düşünmektedir. Bilişsel haritasında da görüleceği gibi Mehmet'e göre teoriler ortam ve koşullardan etkilenmektedir. Ancak Mehmet bu görüşünü savunurken de yine kesin bilginin olup olmadığını sorgulamakta ve yine kendisi ile çelişmektedir. Çünkü bilişsel haritasına bakıldığında Mehmet'e göre bir bilgi \%100 ispatlanmadan kanun olamaz. Ancak Mehmet'in teorilerin değişebileceği ile ilgili olarak vurguladığ 1 bir nokta önemlidir. Şöyle ki Mehmet'e göre belirli şartlar altında bir hipotez defalarca denenip bir sonuca ulaşıldığında ve bunun artık böyle olduğu kabul edildiğinde bile bir sonraki deneyin sonucunun gerçekten öyle olup olmayacağının bilinemeyeceğine dikkat çekerek modern bilim anlayışına uygun bir kavrayış sergilemiştir. Mehmet'in bu soruya ilişkin görüşleri aşağıdaki ifadeler yer almaktadır:

(5.1)Yani zaten hani mutlak bilgi, kesin bilgi diye bir şey, kesin bilgi diye bir şey var mı? Var olsaydı herhalde o zaman gelişime kapalı olmamız gerekirdi... Ortam ve şartlar bire bir oturuyor...

(5.9) Diyelim ki bir aşı yaptık, normal şartlarda o ağaçta o aşı hiç tutmamış. Ama bir milyon defa denendiysek bir milyon birincide tutmayacağı anlamına gelmez...(10)Belki de hani o aşının tutmamasını etkileyen, hani söyleşimizin başında bir süreçten bahsetmiştik hani. Bir milyon defa denedik, teoriye yaklaştı. Bir milyon birinciyi deneme 
şansımız var mı? Var. Ama (11)onu bir kabulleniş olarak diyoruz ki ha bir milyar defa denediysen, bir trilyon defa denediysen bir trilyon birincide de demek ki böyle olur diye çıkarsama yapıyoruz ama bir milyon birincide ne olacağını aslında denememiş oluyoruz.

Alan yazında sıkça karşılaşılan teori ve kanun arasındaki hiyerarşik yapı olduğu kavram yanılgısına Mehmet'in de sahip olduğu bilişsel haritasından görülmektedir. Mehmet'e göre teori tam ispatlanamamış ama kanun tam ispatlanmıştır. Bu konuda Mehmet şunları söylemiştir:

(6.1) teori; ispatlamaya biraz daha muhtaç ama (2)kanun artık tamamen tüm dünyada kabul görmüş, ya da o zamanda yaşayan bütün bilim adamlarınca kabul edilmiş, matematiksel, fiziksel kurallar çerçevesinde ispatlanabilmiş olarak ele alındığını biliyorum.

(6.4)Kanun daha önemli diye biliyorum.

Mehmet'e göre bilim insanları aynı verileri kullanarak farklı sonuçlara bakış açılarının ve zihinsel süreçlerinin farklı olmasından dolayı ulaştıklarını söyleyerek alan yazın ile tutarlı bir açıklama getirmiştir:

(9.1)... olaylara bakış açısı herkesin bakış açısı farklı...(5)Demek ki zihinsel haritamızda oluşturduğumuz yapı, etkileşim o herkese göre değişiklik arz edebiliyor.

Bilimin sosyal ve kültürel değerlerden etkilenip etkilenmediği sorusuna Mehmet etkilendiği yönünde cevap vermiştir. Mehmet'e göre bilimsel süreçler doğal süreçlerle paralellik göstermektedir. Yani insan doğal yaşamında çevresinden nasıl etkileniyorsa bilim de aynı şekilde toplumdan, inançlardan ve değerlerden etkilenmektedir:

(10.4)Burada da şimdi insanlar etkileniyorsa, az önce bahsettik ya tabiatıyla insan bir olay olduğunda etkileniyor. Hani az önce doğallıktan bahsettik ya insanın doğala bakışı. (5)Doğal bir süreçte olaya nasıl tepki veriyorsa bilimsel süreç de aslında benzer şekilde işlediğini düşünüyorum.

Son olarak bilim insanlarının bilimsel süreçlerde hayal güçlerini ve yaratıcılıklarını kullanıp kullanmadığı sorulduğunda bilişsel haritasında da yer aldığı gibi Mehmet, bilimsel süreçlerde hayal gücü ve yaratıcıllğın kullanıldığını düşünmektedir. Ayrıca Mehmet'e göre bilgiyi beyin ürettiği için hayal gücü ve yaratıcılığın kullanılması doğal bir sonuçtur: kurdunuz.

(11.7)Dolayısıyla aslında hayali siz baştan kurdunuz zaten. İşin başında bir hayal

(11.17) Beyin yoluyla bilgi üretiyoruz, kalben bilgi üretmiyoruz, beyinle bilgi üretiyoruz.

\section{Sonuç ve Tartışma}

$\mathrm{Bu}$ çalışmada bir matematik öğretmeninin bilimin doğası hakkındaki görüşleri Abd-ElKhalick tarafından geliştirilen "Bilimin Doğası Hakkındaki Görüşler - Form C" (VNOS-C) anketi kullanılarak derinlemesine incelenmiştir. Elde edilen bulgular özel bir kolejde 12 yıldır matematik öğretmenliği yapmakta olan Mehmet'in bilimin doğası hakkında naif görüşlere sahip olduğunu, yeterli seviyede doğru kavram bilgisine sahip olmadığını göstermektedir. Bu sonuç ilköğretim ve ortaöğretim öğretmenleri ile yaklaşı 50 yıl boyunca yapılan bilimin doğası çalışmalarının, K-12 öğretmenlerinin bilimin doğasının yeterli düzeyde kavramlarına sahip olmadığı (Lederman, 2013) sonucu ile örtüşmektedir. Yine ilgili alan yazında hem hizmet öncesi hem de hizmet içi öğretmenlerin bilimin doğası hakkında naif görüşlere sahip olduğunu belirten birçok çalışma bulunmaktadır (Gheith ve Aljaberi, 2017; Wong vd., 2016; Herman vd., 2015; Aktamış, 2012; Akerson vd., 2010; Çavuş, 2010; Abd-El-Khalick ve Akerson, 2004; Gürses vd., 2005; Akerson ve Abd-El-Khalick, 2003; Abd- El-Khalick and Lederman, 2000; Murcia \& Schibeci, 1999; Pomeroy, 1993).

Mehmet bilimin ölçülebilir, ispatlanabilir olduğunu ve bilgiden geldiğini düşünmektedir. Yine alan yazında sıkça karşılaşılan bilim ve teknolojiyi karıştırma yanılgısına (McComas, 1998) 
sahip değildir. Mehmet teknolojinin bir araç olduğunun farkındadır. İlgili alan yazında ise öğretmenlerin büyük çoğunluğunun bilimi teknoloji ile karıştırdığını bulan çalışmalar bulunmaktadır (Aslan vd., 2009; Doğan Bora, 2005; Tairab, 2001; Yakmac1, 1998; Rubba ve Harkness; 1993).

Bilimde tek bir evrensel yöntemin olduğu ve deney ve gözlem sayısının çokluğu ile bilginin doğruluğu arasında doğru orantı olduğu inancına sahip olan Mehmet' in bu görüşü ilgili alan yazında öğretmenlerin büyük bir bölümünün bilimsel yöntem ile ilgili tek bir yöntem olduğu şeklindeki yetersiz görüşe sahip olduğunu belirten çalışmaların bulguları ile örtüşmektedir (Abd-El-Khalick vd., 2001; McComas, 1998; AAAS, 1990).

Araştırmanın katılımcısı Mehmet teorilerin değişebileceğini düşünmektedir. Mehmet'e göre teoriler ortam ve koşullardan etkilenmektedir. Hatta belirli şartlar altında bir hipotez defalarca denenip bir sonuca ulaşıldığında ve bunun artık böyle olduğu kabul edildiğinde bile bir sonraki deneyin sonucunun gerçekten öyle olup olmayacağının bilinemeyeceğine dikkat çekerek modern bilim anlayışına uygun bir kavrayış sergilemiştir. Bu görüşü Aslan vd. (2009)'ın öğretmenlerle ve Türk vd. (2018)'nin ve Gürses vd. (2005)'ın öğretmen adayları ile yaptıkları çalışmalarında elde ettikleri bilimsel bilgilerin ve teorilerin değişebilen bilgiler olduğu görüşü ile uyumludur. $\mathrm{Bu}$ çalışmadan farklı olarak Murcia ve Schibeci (1999) ise çalışmalarında öğretmenlerin bilim ve bilimsel bilgiyle ilgili yanlış görüşlere sahip olduklarını bulmuşlardır.

Ancak Mehmet bu görüşünü savunurken de yine kesin bilginin olup olmadığını sorgulamakta ve bir bilginin \%100 ispatlanmadan kanun olamayacağını düşünmektedir. Teori ve kanun arasındaki hiyerarşik yapı olduğu kavram yanılgısına Mehmet'in de sahip olduğu görülmektedir. Bu sonuç ilgili alan yazında Aslan vd. (2009) ve Abd-El-Khalick ve Akerson (2004)'un çalışma sonuçları ile benzerlik göstermektedir.

$\mathrm{Bu}$ çalışmada elde edilen diğer bir sonuca göre Mehmet bilim insanlarının bakış açılarının ve zihinsel süreçlerinin farklı olmasından dolayı aynı verileri kullanarak farklı sonuçlara ulaşabileceklerini düşünmektedir. İlgili alan yazında Lederman (2007) ve McComas (2003) bilim insanlarının tutum, inanç, ön bilgileri ve deneyimlerinin araştırma sorularını, veri toplama yöntemlerini ve verileri yorumlama şekillerini etkileyeceğini belirtmekte ve bilim insanlarının objektif davranacak mekanik yapılar olmadığını insan olduklarının vurgulamaktadır.

Yine Mehmet'e göre doğal süreçlerle paralellik gösteren bilimsel süreçler gibi bilim de sosyal ve kültürel değerlerden etkilenmektedir. Bu sonuç ile uyumlu olarak Timur ve Çetin (2018), Buaraphan (2009) ve Aikenhead (1987) bilim ile toplum arasında karşılıklı etkileşim olduğunu ve toplumun ve kültürel değerlerin bilim insanlarının çalışmalarını etkilediğini belirtmektedir. Ancak ilgili alan yazında ne öğretmen adaylarının ne de öğretmenlerin bilimi sosyal bir olgu olarak (Ryan ve Aikenhead, 1992) ve insanın kültürel aktivitesi olarak (McGinn, 1991) görmediklerini bulan çalışmalar bulunmaktadır.

Son olarak bilim insanlarının bilimsel süreçlerde hayal güçlerini ve yaratıcılıklarını kullandığını düşünen Mehmet'in bu görüşü ilgili alan yazındaki çalışmaların sonuçlar ile örtüşmektedir. Bilim insanları merak duydukları konular ile ilgili çalışmalar yapmakta (Çakıc1, 2009) ve yaratıcılık, hayal kurma, dinamiklik ve geçicilik gibi kavramlar bilim ile yakından ilişkilidir (Timur ve Çetin, 2018). Ayrıca Mehmet'e göre bilgiyi beyin ürettiği için hayal gücü ve yaratıcılığın kullanılması doğal bir sonuçtur.

\section{Öneriler}

$\mathrm{Bu}$ başlık altında araştırmada elde edilen sonuçlara dayalı olarak bazı önerilerde bulunulacaktır.

İlk olarak Mehmet'in bilimin doğasına ilişkin bazı naif ve yetersiz anlayışları bulunmaktadır. Mehmet, bilimin çoğunlukla deneye ve gözleme dayalı olduğunu düşünmektedir. Hâlbuki bilim 
teorilere veya yasalara ulaşma çabası olarak ele alındığında aklın rolü deney ve gözlemden daha fazladır. Bilimsel teorilerin temelinde olan hipotezlerin üretilmesi aklın, yaratıcı yeteneğin ve hayal gücünün ürünleridir. Deney ve gözlemler üretilen hipotezden elde edilen çıkarımların kontrolünde (yanlışlanmasında) kullanılmaktadır (Günay, 2003). Bu nedenle öğrencilerin bilimin doğası anlayışlarının gelişmesi için öğretmenlerin de anlayışları mutlaka geliştirilmelidir. Bu bağlamda Mehmet'in üniversite öğrenimi süresince bilimin doğası ile ilişkili hiçbir ders almamış olması nedeniyle ancak hizmet içi eğitim ile bu inanışları yeterli hale getirilebilir. Milli Eğitim Bakanlığı'nın bilimin doğasına ilişkin hizmet içi eğitim programları düzenlemesi ve özel okul öğretmenlerine de bu hizmet içi eğitimlere katılma hakkı verilmesi önerilebilir.

Ayrıca, hizmet içi eğitim programları genellikle kurs veya seminer niteliğinde düzenlendiği için öğretmenler eğitim süresince deneyimleme şansı bulamamaktadır (Kartal vd., 2019). Ancak öğretmenlerin bilimin doğası hakkındaki görüş ve anlayışlarını geliştirmeleri tek başına yeterli olmayıp, bu görüşlerini sınıf ortamına etkili bir şekilde aktarma yollarını bilmeleri (Sorensen, Newton ve McCarthy, 2012) ve bu konudaki öz yeterlilik inançlarını (Mesci, 2016) arttırmalıdır. Bu nedenle düzenlenecek hizmet içi eğitim programlarında öğretmenlere deneyimleme firsatları verilmesi ve devamında öğretmenlerin sınıf içi uygulamalarının da takip edilmesi önerilebilir.

Mehmet'in sahip olduğu yetersiz inanışların diğer bir sebebi sonuç odaklı eğitimler, ezbere yönelik uygulamalar sunan ders kitapları ve yanlış inanışların yaygın bir şekilde kullanılması olabilir (Aslan vd., 2009; İrez, 2008; Aikenhead ve Ryan, 1992). Yine matematik eğitimi özelinde matematiksel terimler genellikle doğaya ya da ampirik dünya ile bağlantısı olmayan zamansız varlıklar ve mekan ve zamanın dışında ideal nesneler ve onlar hakkındaki teorileri de sonsuz gerçekler olarak sunulmaktadır (Kjeldsen ve Lützen 2015). Ancak matematiğin tarihsel bir bağlam içerisinde diğer alanlarla özellikle fizik ile bağlantı kurularak verilmesi matematiksel bilginin nasıl oluştuğunun anlaşılmasını ve matematiğin ve matematik ile ilgili etkinliklerin bilimin doğası ile ilişkilendirilmesini sağlayabilir.

Bilimin doğası ile ilgili 1998 - 2012 yılları arasında yapılan çalışmaları inceleyen Erdaş vd. (2016) Türkiye'de öğretmenlere yönelik çalışmaların kısıtlı olduğunu ve metodolojik kaygılar nedeniyle genellikle öğretmen adayları ve öğrenciler ile bilimin doğasında yönelik çalışmaların yapıldığını belirtmektedir. Bu nedenle bilimsel okuryazar öğrenciler yetiştirmek için farklı disiplinler de dâhil olmak üzere daha çok öğretmen ile çalışma yapılması ve böylece öğretmenlerin bilimin doğasına ilişkin inanışlarının belirlenmesi ve geliştirilmesi önemlidir.

\section{Kaynakça}

Abd-El-Khalick, F., (2006). Over and over and over again: College students' views of nature of science. L.B. Flick \& N.G. Lederman (ed). Scientific inquiry and nature of science: implications for teaching, learning and teacher education. (p 389-425). Netherlands: Springer, https://doi.org/10.1007/1-4020-2672-2_18.

Abd-El-Khalick, F., \& Akerson, V. L. (2004). Learning as conceptual change: Factors mediating the development of preservice elementary teachers' views of nature of science. Science Education, 88(5), 785-810, https://doi.org/10.1002/sce.10143.

Abd-El-Khalick, F., Bell, R. L., \& Lederman, N. G. (1998). The nature of science and instructional practice: Making the unnatural natural. Science Education, 82, 417-436, https://doi.org/10.1002/(sici)1098-237x(199807)82:4<417::aid-sce1>3.0.co;2-e.

Abd-El-Khalick, F., \& Lederman, N. G. (2000). The influence of history of science courses on students' views of nature of science. Journal of Research in Science Teaching, 37(10), 10571095, https://doi.org/10.1002/1098-2736(200012)37:10<1057::aid-tea3>3.0.co;2-c. 
Abd-El-Khalick, F., Lederman, N.G., Bell, R.L., \& Schwartz, R.S. (2001). Views of nature of science questionnaire (VNOS): Toward valid and meaningful assessment of learners' conceptions of nature of science. (Annual International Conference of the Association for the Education of Teachers in Science [AETS]. Costa Mesa, CA, htps://doi.org/10.1002/tea.10034.

Aikenhead, G. (1987). High-school graduates' beliefs about science-technology-society. III. Characteristics and limitations of scientific knowledge. Science Education, 71, 459-487, https://doi.org/10.1002/sce.3730710402.

Aikenhead, G. S., \& Ryan, A. G. (1992). The development of a new instrument:'Views on ScienceTechnology-Society'(VOSTS). Science Education, 76(5), 477-491, https://doi.org/10.1002/sce.3730760503.

Akerson, V. L., Abd -El-Khalick, F. (2003). Teaching elements of nature of science: A yearlong case study of a fourth grade teacher. Journal of Research in Science Teaching, 40, 1025-1049, https://doi.org/10.1002/tea.10119.

Akerson, V. L., Buzzelli, C. A., \& Donnelly, L. A. (2010). On the nature of teaching nature of science: Preservice early childhood teachers' instruction in preschool and elementary settings. Journal of Research in Science Teaching: The Official Journal of the National Association for Research in Science Teaching, 47(2), 213-233, https://doi.org/10.1002/tea.20323.

Akgün, Z., \& Özenoğlu, H. (2018). Sınıf öğretmenlerinin bilimin doğasına yönelik görüşleri. Adnan Menderes Üniversitesi Eğitim Fakültesi Ĕ̆itim Bilimleri Dergisi, 9(2), 165-190, https://doi.org/10.17556/jef.65883.

Aktamış, H. (2012). How prospective mathematics teachers view the nature of science. ProcediaSocial and Behavioral Sciences, 31, 690-694, https://doi.org/10.1016/j.sbspro.2011.12.126.

American Association for the Advancement of Science [AAAS]. (1990). Science for all Americans. New York: Oxford University Press.

Aslan, O., Yalçin, N., \& Taşar, M. F. (2009). Fen ve teknoloji öğretmenlerinin bilimin doğası hakkındaki görüşleri. Ahi Evran Üniversitesi Kırşehir Eğitim Fakültesi Dergisi, 10(3), 1-8, https://doi.org/10.19171/uuefd.93591.

Association for Career and Technical Education, National Association of State Directors of Career Technical Education Consortium and Partnership for 21st Century Skills. (2010). Up to the challenge: The role of career and technical education and 21st century skills in college and career readiness, https://doi.org/10.21061/jcte.v27i2.559, http://www.p21.org/storage/documents/CTE_Oct2010.pdf adresinden 1.10.2019 tarihinde indirildi.

Bakanay, Ç.D. (2008). Biyoloji ögrretmen adaylarının evrim teorisine yaklaşımları ve bilimin doğasına baklş açıları. Yayımlanmamış yüksek lisans tezi, Marmara Üniversitesi, İstanbul.

Balc1, A. (2011). Sosyal bilimlerde araştırma yöntem, teknik ve ilkeler (9. Bask1). Ankara: Pegem Akademi Yayıncilık.

Bilen, K. (2012). Bilimin doğası dersinde örnek bir uygulama: Kart değişim oyunu. Mustafa Kemal Üniversitesi Sosyal Bilimler Enstitüsü Dergisi, 9(18), 173-185, https://doi.org/10.17218/husbed.01508.

Bogdan, R. C. \& Biklen, S. K. (1992). Qualitative research for education: An introduction to theory and methods. Boston: Allyn and Bacon. 
Buaraphan, K. (2009). Pre-service and in-service science teachers' responses and reasoning about the nature of science. Educational Research and Review, 4 (11), 561-581.

Büyüköztürk, Ş. ve diğ. (2013). Bilimsel araştırma yöntemleri (15. Baskı). Ankara: Pegem Akademi Yayıncilik

Bybee, R. W. (2010). The teaching of science: 21 st century perspectives. Arlington, Virginia: NSTA Press.

Cavus, S., Dogan, N., \& Gungoren, S. (2011). What do pre-service science and mathematics teachers' views about scientific theories and laws?. In Committee of the International Symposium on Integrating Research, Education, and Problem Solving (IREPS 2011), November.

Çakıcı, Y. (2009). Fen eğitiminde bir önkoşul: bilimin doğasını anlama. Marmara Üniversitesi Atatürk Eğitim Fakültesi Eğitim Bilimleri Dergisi, 29(29), 57-74, https://doi.org/10.24315/trkefd.305999.

Çalışkan, S., Sezgin Selçuk, G. ve Demircioğlu, S. (2015). Fizik öğretmen adaylarının bilimin doğası temelinde fiziğin doğasına yönelik görüşleri. Turkish Studies, 10(15), 197-216, https://doi.org/10.7827/turkishstudies.8774.

Çelik, S., \& Karataş, F. Ö. (2016). Öğretmen adaylarının bilimin doğasına yönelik anlayışları ile öğrenim gördükleri alanlar arasındaki ilişki. Kastamonu Ĕ̆itim Dergisi, 23(2), 755-772, https://doi.org/10.24106/kefdergi.3357.

Çavuş, S. (2010). İlköğretim fen bilgisi ve matematik öğretmenliği lisans öğrencilerinin bilimin doğası hakkındaki görüşlerinin geliştirilmesi. Yayımlanmamış yüksek lisans tezi. Bolu: Abant İzzet Baysal Üniversitesi.

Çınar, M., \& Köksal, N. (2013). Sosyal bilgiler öğretmen adaylarının bilime ve bilimin doğasına yönelik görüşleri. Mersin Üniversitesi Eğitim Fakültesi Dergisi, 9(2), 43-57, https://doi.org/10.18506/anemon.471414.

DeBoer, G. E. (2000). Scientific literacy: Another look at its historical and contemporary meanings and its relationship to science education reform. Journal of Research in Science Teaching: The Official Journal of the National Association for Research in Science Teaching, 37(6), 582-601, https://doi.org/10.1002/1098-2736(200008)37:6<582::aid-tea5>3.0.co;2-1.

Demir, A. (2018). Endüstri 4.0'dan Eğitim 4.0'a değiş̧en eğitim öğretim paradigmaları. Electronic $\begin{array}{lllll}\text { Turkish } \quad \text { Studies, } & \text { 13(15), } & \text { Spring }\end{array}$ https://doi.org/10.7827/turkishstudies.13480.

Deveci, Ö. (2010). Illköğretim altıncı sinıf fen ve teknoloji dersi kuvvet ve hareket ünitesinde fenmatematik entegrasyonunun akademik başarı ve kalıcılık üzerine etkisi. Yayımlanmamış yüksek lisans tezi, Çukurova Üniversitesi Sosyal Bilimler Enstitüsü, Adana.

Dikmentepe, E., \& Yakar, Z. (2016). Preservice science teachers' views on science technology society. International Journal of Higher Education, 5(2), 183-195, https://doi.org/10.5430/ijhe.v5n2p183.

Doğan Bora, N. (2005). Türkiye genelinde ortä̈gretim fen bransı öğretmen ve ögrencilerinin bilimin doğası üzerine görüslerinin arastırılması. Yayınlanmamış doktora tezi. Gazi Üniversitesi, Ankara.

Doğanay, A., Demircioğlu, T., \& Yeşilpınar, M. (2014). Öğretmen adaylarına yönelik bilimin doğası konulu disiplinler arası öğretim programı geliştirmeye ilişkin bir ihtiyaç analizi çalışması. Turkish Studies, 9(5), 777-798, https://doi.org/10.7827/turkishstudies.6725. 
Driver, R., Leach, J., Millar, R., \& Scott, P. (1996). Young people's ımages of science. Buckingham: Open University Press.

Dursun, B. \& Özmen, N. (2018). Fen bilgisi öğretmen adaylarının bilimin doğası ve teknoloji hakkındaki görüşleri. Eğitim Bilimleri Araştırma Dergisi, 8(1), 55-71, https://doi.org/10.22521/jesr.2018.81.2.

Erdaş, E., Doğan, N., \& İrez, S. (2016). Bilimin doğasıyla ilgili 1998-2012 yılları arasında Türkiye'de yapılan çalışmaların değerlendirmesi. Kastamonu Eğitim Dergisi, 24(1), 17-36, https://doi.org/10.17943/etku.351473.

Gheith, E., \& Aljaberi, N. M. (2017). The conceptions of pre-service kindergarten and elementary school teachers on teaching science and the nature of science. Advances in Social Sciences Research Journal, 4(2), https://doi.org/10.14738/assrj.41.2532.

Goetz, J. P. \& LeCompte, M. D. (1984). Ethnography and qualitative design in educational research. Orlando: Academic Press.

Gücüm, B. (2000). Fen bilgisi öğretmenliği ögrencilerinin bilimsel bilginin yapısını anlama düzeyleri üzerine bir araştırma. IV. Fen Bilimleri Eğitimi Kongresi. Ankara: Hacettepe Üniversitesi Eğitim Fakültesi, https://doi.org/10.17522/balikesirnef.623851.

Günay, D. (2003). Bilimin matematiksel (olan) temeli, İstanbul Kültür Üniversitesi Yayınları, Bildiriler Kitabı, Mantık, Matematik ve Felsefe I. Ulusal Sempozyumu, 26-28 Eylül 2003, Assos-Çanakkale.

Gürel, Z. (2002). Resim bölümü ögrencilerinin fen bilimleri doğasını anlama biçimleri. V. Ulusal Fen Bilimleri ve Matematik Eğitimi Kongresi, Ankara: ODTÜ.

Gürses, A., Doğar, Ç., \& Yalçın, M. (2005). Bilimin doğası ve yükseköğrenim öğrencilerinin bilimin doğasına dair düşünceleri. Milli Eğitim Dergisi, 33(166), 68- 76.

Herman, B. C., Clough, M. P., \& Olson, J. K. (2017). Pedagogical reflections by secondary science teachers at different NOS implementation levels. Research in Science Education, 47(1), 161184, https://doi.org/10.1007/s11165-015-9494-6.

Hurd, P. D. (1998). Scientific literacy: New minds for a changing world. Science Education, 82, 407416, https://doi.org/10.1002/(sici)1098-237x(199806)82:3<407::aid-sce6>3.0.co;2-g.

İrez, S. (2006). Are we prepared?: An assessment of pre-service science teacher educators' beliefs about nature of science. Science Education, 90(6), 1113-1143, https://doi.org/10.1002/sce.20156.

İrez, S. (2008). Nature of science as depicted in Turkish biology textbooks. Science Education, 93(3), 422-447, https://doi.org/10.1002/sce.20305.

Jenkins, E. W. (1997). Scientific and technological literacy for citizenship: what can we learn from the research and other evidence. S. Sjoberg and E. Kallerud (Eds.), Science, technology and citizenship: The public understanding of science and technology in science education and research policy. (pp. 29-50). Oslo: Norwegian Institute for Studies in Research and Higher Education.

Kartal, E. E., Doğan, N., İrez, S., Çakmakçı, G., \& Yalaki, Y. (2019). Mesleki gelişim programı: Öğretmenlerin bilimin doğasını öğrenme ve öğretme inançları. Ĕgitim ve Bilim, 44(198), https://doi.org/10.15390/eb.2019.7690. 
Kenar, Z. (2008). Fen bilgisi öğretmen adaylarının bilimin doğası hakkındaki görüşleri. Yayımlanmamış yüksek lisans tezi, Balıkersir Üniversitesi Fen Bilimleri Enstitüsü, Balıkesir.

Kızılcık, H.Ş., Temiz, B.K., Tan, M., \& İngenç, Ş.K. (2007). Sözel bölümü öğretmen adaylarının fen bilimlerine, fen eğitimine ve teknolojiye karşı tutumlarının araştırılması. Eğitim ve Bilim, 32(146), 80-89, https://doi.org/10.17522/balikesirnef.660540.

Khishfe, R., \& Lederman, N. (2006). Teaching nature of science within a controversial topic: Integrated versus nonintegrated. Journal of Research in Science Teaching: The Official Journal of the National Association for Research in Science Teaching, 43(4), 395-418, https://doi.org/10.1002/tea.20137.

Kjeldsen, T. H., \& Lützen, J. (2015). Interactions between mathematics and physics: The history of the concept of function - teaching with and about nature of mathematics. Science \& Education, 24(5-6), 543-559, https://doi.org/10.1007/s11191-015-9746-X.

Lederman, N. G. (1992). Students' and teachers' conceptions of the nature of science: a review of the research. Journal of Research in Science Teaching, 29(4), 331-359, https://doi.org/10.1002/tea.3660290404.

Lederman, N. G. (1998). The state of science education: subject matter without content. Electronic Journal of Science Education, 3(2), 1-12.

Lederman, N. G. (2000). Teachers' understanding of the nature of science and classroom practice: factors that facilitate or impede the relationship. Journal of Research in Science Teaching, 36(8), 916-929, $\quad$ https://doi.org/10.1002/(sici)1098-2736(199910)36:8<916::aidtea2>3.0.co;2-a.

Lederman, N. G. (2007). Nature of science: Past, present, and future. In S. K. Abell, \& N. G. Lederman, (Eds.), Handbook of research on science education (pp. 831-880). Mahwah, New Jersey: Lawrence Erlbaum Associates.

Lederman, N. G. (2013). Nature of science: Past, present, and future. In Handbook of research on science education (pp. 845-894). Routledge.

Lederman, N. G., Abd-El-Khalick, F., Bell, R., \& Schwartz, R. (2002). Views of nature of science questionnaire: Toward valid and meaningful assessment of learners' conceptions of nature of science. Journal of Research in Science Teaching, 39(6), 497-521, https://doi.org/10.1002/tea.10034.

Lederman, N.G., Lederman, J.S., \& Antink, A. (2013). Nature of science and scientific inquiry as contexts for the learning of science and achievement of scientific literacy. International Journal of Education in Mathematics, Science and Technology, 1(3).

McComas, W. F. (1998). The principal elements of the nature of science: Dispelling the myths. W. F. McComas (Ed.), The Nature of Science in Science Education: Rationales and Strategies (p 53-70). Dordrecht: Kluwer Academic Publishers, https://doi.org/10.1007/0-306-4721553 .

McComas, W. F. (2003). A textbook case of the nature of science: Laws and theories in the science of biology. International Journal of Science and Mathematics Education, 1 (2), 141-155, https://doi.org/10.1023/b:ijma.0000016848.93930.9c.

McComas, W. F., Clough, M.P., \& Almozroa, H. (1998). The role and character of the nature of science in science education. W. F. McComas (Ed.), The Nature of Science in Science 
Education: Rationales and Strategies (p 3-39). Dordrecht: Kluwer Academic Publishers, https://doi.org/10.1007/0-306-47215-5_1.

McComas, W. F. \& Wang, H. A. (1998). Blended science: The rewards and challenges of integrating the science disciplines for instruction. School Science and Mathematics, 98(6), 340-348, https://doi.org/10.1111/j.1949-8594.1998.tb17430.x.

McGinn, R. (1991) Science, technology and society. New Jersey: Prentice Hall.

Mellado, V. (1998). The classroom practice of preservice teachers and their conceptions of teaching and learning science. Science Education, 82(2), 197-214, https://doi.org/10.1002/(sici)1098237x(199804)82:2<197::aid-sce5>3.0.co;2-9.

Mesci, G. (2016). Preservice science teachers' pedagogical content knowledge for nature of science and nature of scientific inquiry: A successful case study (Yayımlanmamıs doktora tezi). Western Michigan University, MI, USA.

Milli Eğitim Bakanlığı (MEB) (2013). Ortaokul matematik dersi öğretim programı (5, 6, 7 ve 8. siniflar).

Milli Eğitim Bakanlığı (MEB) (2017a). Ortaokul matematik dersi ögretim programı (5, 6, 7 ve 8. siniflar).

Milli Eğitim Bakanlığı (MEB) (2017). Fen bilimleri dersi öğretim programı. Ankara.

Milli Eğitim Bakanlığı (MEB) (2018a). Fen bilimleri dersi öğretim programı. Ankara.

Milli Eğitim Bakanlığı (MEB) (2018b). Matematik dersi öğretim programı. Ankara.

Moscovici, H., \& Newton, D. (2006). On my mind: Math and science: A natural connection? Mathematics Teaching in the Middle School, 11(8), 356-358

Moss, D. M. (2001). Examining students' conception of the nature of science. International Journal of Science Education. 23(8), 771-790.

Murcia, K., \& Schibeci, R. (1999). Primary student teacher' conceptions of the nature of science. International Journal of Science Education, 21(11), 1123-1140, https://doi.org/10.1080/095006999290101.

National Research Council [NRC] (1996). National science education standards. Washington, DC: National Academies Press.

National Science Teachers Association [NSTA] (2000). NSTA position statement. Web sayfasi: http://www.nsta.org/positionstatement\&psid=22

Organization for Economic Co-operation and Development (OECD). (2006). Assessing scientific, reading and mathematical literacy: A framework for PISA 2006. Paris: Author, https://doi.org/10.1787/9789264026407-en.

Organization for Economic Co-operation and Development (OECD). (2013). PISA 2015: Draft science framework. http://www.oecd.org/pisa/pisaproducts adresinden 4.10.2019 tarihinde indirildi.

Patton, M. Q. (1987). How to use qualitative methods in evaluation. Newbury Park, CA: Sage.

Pomeroy, D. (1993). Implications of teachers' beliefs about the nature of science: Comparison of the beliefs of scientists, secondary science teachers, and elementary teachers. Science Education, 77 (3), 261-278, https://doi.org/10.1002/sce.3730770302. 
Rubba, P. A. \& Harkness, W. L. (1993). Examination of preservice and in-service secondary science teachers' beliefs about science-teachnology-society interactions. Science Education, 77(4): 407-431, https://doi.org/10.1002/sce.3730770405.

Ryan, A. G., \& Aikenhead, G.S. (1992). Students' preconceptions about the epistemology of science. Science Education, 76(6), 559-580, https://doi.org/10.1002/sce.3730760602.

Saraç, E.(2002). Sinıf ögretmenleri ve sınıf öğretmeni adaylarının bilimin doğasına ilişsin görüşleri. Yayımlanmamış yüksek lisans tezi, Akdeniz Üniversitesi, Antalya.

Seferoğlu, S. S. (2015). Okullarda teknoloji kullanımı ve uygulamalar: Gözlemler, sorunlar ve çözüm önerileri. Artı Ĕgitim, 123, 90-91, https://doi.org/10.17051/ilkonline.2018.466425.

Shamos, M. (1995). The myth of scientific literacy. New Brunswick, NJ: Rutgers University Press.

Sorensen, P., Newton, L., \& McCarthy, S. (2012) Developing a science teacher education course that supports student teachers' thinking and teaching about the nature of science. Research in $\begin{array}{llll}\text { Science } \& \text { Technological 29-47, } & \end{array}$ https://doi.org/10.1080/02635143.2012.671767.

Stake, R. E. (1995). The art of case study research. California: Sage Publications.

Subaşı, B., Dinler, A. (2003). Dünya'da ve Türkiye'de özel okullar. İstanbul: İTO Yayınları.

Suchting, W. A. (1995). The nature of scientific thought. Science \& Education, 4(1), 1-22.

Süzük, E., Ogan-Bekiroğlu, F. (2017). Temel bilimlere azalan ilgiye karşllık kavramsal bir öneri: Fizik kimliği, Route Educational and Social Science Journal, 4(5), 50-60, https://doi.org/10.17121/ressjournal.732.

Tairab, H. H. (2001). How do pre-service and in-service science teachers view the nature of science and technology?. Research in Science \& Technological Education, 19(2), 235-250, https://doi.org/10.1080/02635140120087759.

Tatar, E., Karakuyu, Y., \& Tüysüz, C. (2011). Sınıf öğretmeni adaylarının bilimin doğası kavramları: Teori, yasa ve hipotez/Prospective primary school teachers' concepts of the nature of science: theory, law and hypothesis. Mustafa Kemal Üniversitesi Sosyal Bilimler Enstitüsü Dergisi, 8(15), 363-370, https://doi.org/10.12780/uusbd.91305.

Timur, B., \& Çetin, N. İ. (2018). Examination teachers' opinions about the nature of science. European Journal of Education Studies. 4(10), 99-109.

Tsai, C. (1998). An analysis of scientific epistemological beliefs and learning orientations of taiwanese eight graders. Science Education, 82, 473-489, https://doi.org/10.1002/(sici)1098237x(199807)82:4<473::aid-sce4>3.0.co;2-8.

Tufan, E. (2007). Müzik öğretmen adaylarının bilimin doğası hakkındaki görüşleri. Gazi Eğitim Fakültesi Dergisi, 27(3), 99-105, https://doi.org/10.21764/maeuefd.402689.

Turgut, H., Akçay, H., \& İrez, S. (2010). Bilim sözde-bilim ayrımı tartışmasının öğretmen adaylarının bilimin doğası inanışlarına etkisi. Kuram ve Uygulamada Eğitim Bilimleri, 10(4), 2621-2663, https://doi.org/10.14527/9786052410660.02.

Türk, C., Yıldırım, B., Bolat, M., \& İskeleli, N. O. (2018). Okul öncesi öğretmen adaylarının bilimin doğasına yönelik görüşleri. Anemon Muş Alparslan Üniversitesi Sosyal Bilimler Dergisi, 6(STEMES'18), 115-121, https://doi.org/10.18506/anemon.471414. 
Uygun, S. (2003). Türkiye'de dünden bugüne özel okullara bir bakış (gelişim ve etkileri). Ankara Üniversitesi Eğitim Bilimleri Fakültesi Dergisi, 36(1), 107-120, https://doi.org/10.1501/egifak_0000000083.

Yakmac1, B. (1998). Science (biology, chemistry and physics) teachers' views on the nature of science as a dimension of scientific literacy. Yayınlanmamış yüksek lisans tezi, Boğaziçi Üniversitesi, İstanbul.

YÖK, 2020. Ĕgitim fakültesi öğretmen yetiştirme lisans programlarl. https://www.yok.gov.tr/yayinlar/yayinlarimiz adresinden 18.03.2020 tarihinde indirildi.

Yüce, Z., \& Önel, A. (2015). Fen öğretmen adaylarının bilimin doğasını anlamaları ve evrim teorisini kabul düzeylerinin belirlenmesi. Electronic Turkish Studies, 10(15), https://doi.org/10.7827/turkishstudies.8476.

Wagner, T. (2008). Rigor redefined. Educational Leadership, 66(2), 20-24.

Windschitl, M. (2009). Cultivating 21st century skills in science learners: How systems of teacher preparation and professional development will have to evolve. Paper commissioned by National Academy of Science's Committee on The Development of 21 st Century Skills. Washington, DC.

Wong, V., \& Dillon, J. (2019). 'Voodoo maths', asymmetric dependency and maths blame: Why collaboration between school science and mathematics teachers is so rare. International Journal of Science Education, 41(6), 782-802, https://doi.org/10.1080/09500693.2019.1579945.

Wong, S.S., Firestone, J.B., Ronduen, L.G., \& Bang, E.J. (2016). Middle school science and mathematics teachers "e conceptions of the nature of science: A one-year study on the effects of explicit and reflective online instruction. International Journal of Research in Education and Science (IJRES), 2(2), 469-482, https://doi.org/10.21890/ijres.56557.

Yıldırım, C. (2008). Bilim tarihi, 11. Edition, İstanbul: Remzi Kitabevi.

Yıldırım, A. ve Şimşek, H. (2013). Sosyal bilimlerde nitel araştırma yöntemleri (9.baskı). Ankara: Seçkin Yayıncılık.

Zeybekoğlu, A. Z. (2008). Pazarlama ve özel okullar: Okul müdürlerinin hedef pazarlamadaki rolü. Milli Eğitim Dergisi, 177, 294-304. 